\title{
Chemical Papers
}

\section{A Spectrophotometric and DFT study of the behavior of 6-bromoquercetin in aqueous solution}

\author{
--Manuscript Draft--
}

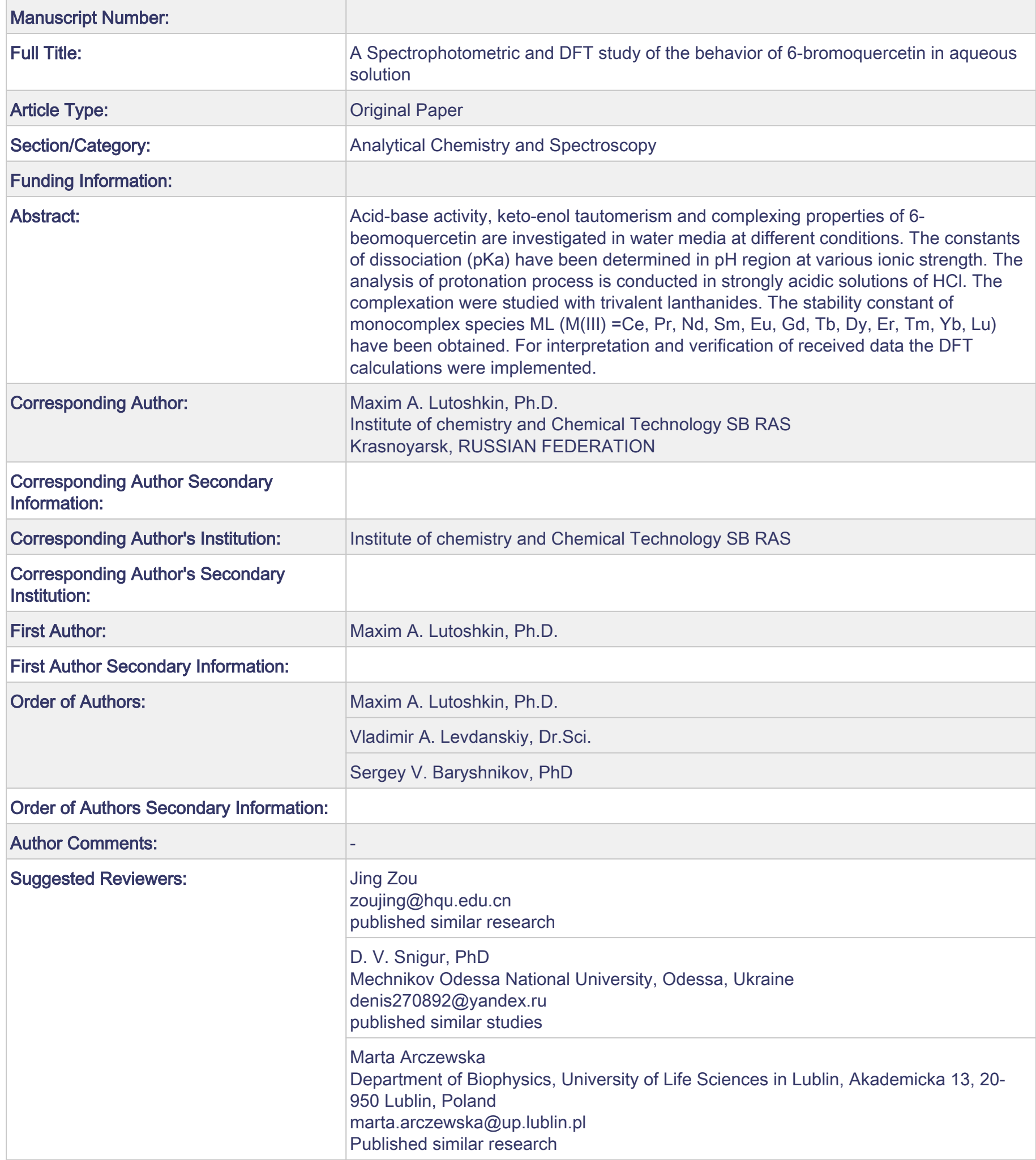




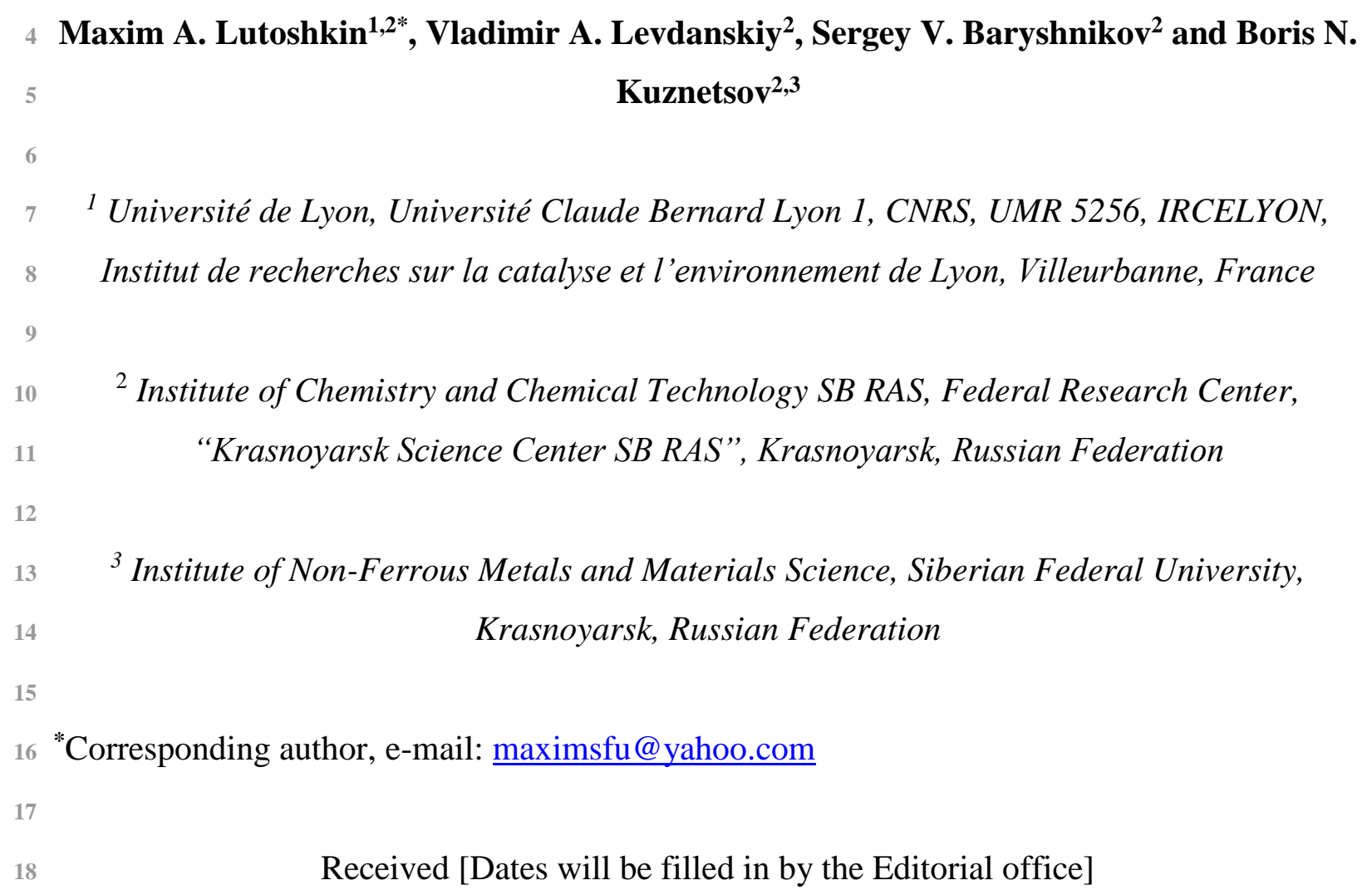

A Spectrophotometric and DFT study of the behavior of 6-bromoquercetin in aqueous solution 
23

25 b

26

27 O

28 studied with trivalent lanthanides. The stability constant of monocomplex species ML (M(III) $29=\mathrm{Ce}, \mathrm{Pr}, \mathrm{Nd}, \mathrm{Sm}, \mathrm{Eu}, \mathrm{Gd}, \mathrm{Tb}, \mathrm{Dy}, \mathrm{Er}, \mathrm{Tm}, \mathrm{Yb}, \mathrm{Lu})$ have been obtained. For interpretation and 30 verification of received data the DFT calculations were implemented.

31

Keywords: DFT, Flavonoids, Lanthanide, Spectrophotometric.

Introduction

36

Being secondary metabolites, flavonoids exist ubiquitous in the plant world (Panche et 38 al. 2016). Quercetin or 5,7,3',4'-flavon-3-ol is the most known and studied ligand from this 39 group of chemicals. The various qualities, such as anticancer (Le Marchand 2002), antibacterial 40 (Cushnie and Lamb, 2005) and antidiabetic (Vinayagam and Xu 2015) activities demonstrate a 41 multifaceted nature of quercetin. The numerous derivatives of quercetin are also show notable 42 biochemical characteristics (Kessler et al 2003; Sotnikova et al 2013; Manach et al 1998). The 43 complexes of flavonoids with all of groups of metals (Kasprzak et al. 2015; Samsonowicz and 44 Regulska 2017) are described in literature primarily for solid-state conditions.

The flavonoids exhibit medical and biological properties in water. Nevertheless, 46 the low solubility make them problematic objects for study of standard physical-chemical methods. The solubility of quercetin in $\mathrm{H}_{2} \mathrm{O}$ at room temperature is about $10^{-4} \mathrm{M}$ (Srinivas et 48 al. 2010). In the same time, the necessary concentration for NMR-analysis or potentiometric 49 study is $10^{-2}-10^{-1} \mathrm{M}$. In all works where the issue of flavonoids in solution has been discussed 50 the water-ethanol mixtures or non-aqueous liquids were used as solvent. However, under such 51 conditions the behaviour of flavonoids is fundamentally different from biological media. The 52 spectrophotometric technique is one of the few methods that allow to research small amount of 53 sparingly soluble compounds and determine all equilibrium parameters in pure water with 54 concentration $<10^{-4} \mathrm{M}$. 
The rare-earth elements (REEs) have the typical characteristics of trivalent metals in

\section{Theoretical}

64 The values of dissociation constant $\left(\mathrm{pK}_{\mathrm{a}}\right)$ have been calculated using equation (Leggett 1985):

$$
A_{i}=\frac{C_{H L}\left(\varepsilon_{L^{-}} \cdot K_{a}+\varepsilon_{H L}\left[H^{+}\right]\right)}{K_{a}+\left[H^{+}\right]},
$$

66 with the Henderson-Hasselbach equation (Tiwari and Ghosh 2010):

$$
\mathrm{pH}=p K_{a}+\log (\mathrm{IR}) ; \quad I \mathrm{R}=\frac{A_{i}-A_{H L}}{A_{L^{-}}-A_{i}},
$$

68 where IR - ionization ratio.

69 The non-linear Cox-Yates method (Cox 1983) based on the excess acidity function $\chi$ (Cox 70 1981) was used to determine the protonation constant $\left(K_{H}\right)$ in strongly acidic solutions:

$$
A_{i}=\frac{A_{H L}-A_{H_{2} L^{+}}}{1+\left(\frac{C_{H^{+}}}{K_{H}}\right) 10^{\left(m^{*} \chi\right)}}+A_{H_{2} L^{+}} ;
$$

where $\mathrm{A}_{\mathrm{i}}, \mathrm{A}_{\mathrm{HL}}\left(\varepsilon_{\mathrm{HL}}\right), \mathrm{A}_{\mathrm{H} 2 \mathrm{~L}+}\left(\varepsilon_{\mathrm{H} 2 \mathrm{~L}+}\right)$, and $\mathrm{A}_{\mathrm{L}-}\left(\varepsilon_{\mathrm{L}-}\right)$ are the absorbances and molar extinction 73 coefficients of the process solution, the free ligands, and its conjugate acid or base, respectively. 74 Conditional stability constants (K') for monocomplex species were calculated from the 75 equations 1-2 (Grebenyuk et al. 2015):

$$
\begin{aligned}
& A_{\text {calc }}^{\lambda}=\varepsilon_{H L}^{\lambda}\left(C_{H L}-[M L]\right)+\varepsilon_{M}^{\lambda}\left(C_{M}-[M L]\right)+\varepsilon_{M L}^{\lambda}[M L], \\
& {[M L]=1 / 2\left[\left(1 / K^{\prime}+C_{H L}+C_{M}\right)+\sqrt{\left(1 / K^{\prime}+C_{H L}+C_{M}\right)-4 C_{M} C_{H L}}\right] \text {, }}
\end{aligned}
$$

78 where $A_{\text {calc }}^{\lambda}$ is an absorbance at a given wavelength and $\mathrm{C}_{\mathrm{M}}$ and $\mathrm{C}_{\mathrm{HL}}$ were analytical 79 concentrations of lanthanides and ligand, respectively. The $\varepsilon^{\lambda}$ is a value of molar extinction 80 coefficient at single wavelength. The optimal values for $\mathrm{K}^{\prime}, \mathrm{K}_{\mathrm{a}}$ and $\mathrm{K}_{\mathrm{H}}$ and $\varepsilon^{\lambda}$ were found from 81 the least squares analysis (Leggett 1985):

$$
f\left(C_{M}, C_{L}, K^{\prime}, \varepsilon_{i}\right)=\sum_{i=1}^{n}\left(A_{i}^{\lambda}-A_{i}^{\text {calc }}\right)^{2} \stackrel{K, \varepsilon_{i}}{\longrightarrow} \min .
$$


33 Calculations of all equilibrium constants and molar extinction coefficients were performed using Wolfram Mathematica (http://www.wolfram.com/).

The quantum-chemical computations were performed using the GAMESS US (Schmidt 1993) program package on the cluster MVS-1000M of the Institute of computational modeling 87 SB RAS. Geometry optimization was performed by density functional theory (DFT) with seven 88 functionals: PBE0 (Adamo and Barone 1999) (under Grimme's empirical correction (Grimme 89 et al. 2010)), revTPSS (Perdew et al. 2011), M06-2L; M06; M06-2X; M06-HF (Zhao and 90 Truhlar 2008) and CAM-B3LYP (Yanai and Tew 2004). The cc-pVDZ (Dunning 1989) basis 91 set functions was applied at $\mathrm{C}, \mathrm{H}, \mathrm{O}$ and $\mathrm{Br}$ atoms. The solvent effects were evaluated using the 92 SMD solvation model (Marenich et al. 2009). The calculation of equilibrium constants were performed be following equation (Bryantsev et al. 2008):

94

96

$$
\Delta \Delta \mathrm{G}^{\text {solv. }}=\Delta \mathrm{G}^{\text {gas }}+\Delta \mathrm{G}^{\text {aq. }}+\Delta \mathrm{E}^{\text {zpe }}-\mathrm{E}^{\text {corr. }}
$$

98 , where

$$
\mathrm{E}^{\text {corr. }}=\mathrm{RT} \ln \left(\left[\mathrm{H}_{2} \mathrm{O}\right]\right)=9.964 \mathrm{~kJ} / \mathrm{mol} \text {. }
$$

101 Here, $R T \ln \left(\left[\mathrm{H}_{2} \mathrm{O}\right]\right)$ is a free energy change associated with moving a solvent from a standard102 state solution phase concentration of $1 \mathrm{M}$ to a standard state of the pure liquid, $55.34 \mathrm{M}$ 103 (Vukovic et al. 2015). The change of Gibbs free energy in solid state and in solution $\left(\Delta \mathrm{G}^{\text {gas }}\right.$ and $\left.104 \Delta \mathrm{G}^{\text {aq. }}\right)$. $\mathrm{E}^{\text {zpe }}$ is calculated harmonic vibrational frequencies to estimate the zero point energy 105 correction.

\section{Experimental}

109 The UV-Vis spectra were measured with Leki SS2109-UV scanning spectrophotometer (Leki 110 Instruments, Finland) using $1 \mathrm{~cm}$ quartz cells. Cell thermostating $( \pm 0.1 \mathrm{~K})$ was performed with 111 the Haake K15 thermostat connected to the Haake DC10 controller. All measurements were 112 performed at $298 \mathrm{~K}$. The synthesis of bromine derivative of quercetin was performed by the 113 simple method described at (Nagimova et al. 1996): $1 \mathrm{~g}$ of quercetin was brominated in dioxane 114 at $298 \mathrm{~K}$ without stirring (Scheme 1). The precipitated orange crystals were washing with water 115 and crystallize three times from ethanol. The test by paper chromatography have been 116 demonstrate the absence of initial quercetin in the final products. 
117<smiles>O=c1c(O)c(-c2ccc(O)c(O)c2)oc2cc(O)cc(O)c12</smiles><smiles>O=c1c(O)c(-c2ccc(O)c(O)c2)oc2cc(O)c(Br)c(O)c12</smiles>

Scheme 1. The synthesis of 6-bromoquercetin.

119

\section{Materials}

121

\section{Chemicals}

All chemicals were of analytical grade: quercetin (Aldrich $\geq 95 \%, \mathrm{HPLC}$ ), $\mathrm{CH}_{3} \mathrm{COONa}$, $\mathrm{CH}_{3} \mathrm{COOH}$, citric acid, TRIS, $\mathrm{Na}_{2} \mathrm{HPO}_{4}$, glycine, $\mathrm{Br}_{2}, \mathrm{NaClO}_{4}, \mathrm{HCl}, \mathrm{LnCl}_{3} \cdot 6 \mathrm{H}_{2} \mathrm{O}(\mathrm{Ln}=\mathrm{Ce}, \mathrm{Pr}$, $125 \mathrm{Nd}, \mathrm{Sm}, \mathrm{Eu}, \mathrm{Gd}, \mathrm{Tb}, \mathrm{Dy}, \mathrm{Er}, \mathrm{Tm}, \mathrm{Yb}$ ). All stock solutions were obtained by dissolution of dry 126 salts and ligand weights. The solutions of bromquercetin were prepared from its ethanol 127 concentrated solution $\left(\mathrm{C}=6 \cdot 10^{-3} \mathrm{M}\right)$. The concentration of ethanol did not exceed $1 \%$ in the final 128 solution. Buffer solutions within the $\mathrm{pH}$ range from 1.80 to 3.60 were prepared with glycine 129 and $\mathrm{HCl}$, from 3.60 to 5.60 with $\mathrm{CH}_{3} \mathrm{COOH}$ and $\mathrm{CH}_{3} \mathrm{COONa}$ (for study of complexation), from 1303.60 to 7.00 with citric acid and $\mathrm{Na}_{2} \mathrm{HPO}_{4}$ (for study of dissociation), from 7.00 to 8.60 with 131 TRIS and $\mathrm{HCl}$. The accurate desired $\mathrm{pH}$ values were obtained by adjusting the molarities of the 132 buffer components in suitable amounts. The accurate concentration of $\mathrm{Ln}^{3+}$ has been establish 133 by complexometric titration with EDTA.

,

\section{Results and discussion}

3.1 The study of acid-base properties

The various states of investigated flavonoid have the different shape of electronic spectra. Fig. 1 demonstrate the spectra of neutral, protonated and monoanionic forms of 41 quercetin and 6-bromoqiercetin. In Table 1 represent the position of absorption maximum for 142 bromoquercetin compared with pure quercetin. There is linear relationship between optical 143 density and concentration for all forms of BQR. Thus, the formation of ionic associate or dimers 144 are not taking place. The interaction between components of used buffers and ligand is not find. 
47 Table 1. The values of wavelength $(\mathrm{nm})$ of main absorbance peaks of BQR and quercetin 148

\begin{tabular}{ccccc}
\hline \multirow{2}{*}{ Form } & \multicolumn{2}{c}{ 6-Bromoquercetin } & \multicolumn{2}{c}{ Quercetin } \\
& $\lambda^{\text {max, } 1}$ & $\lambda^{\text {max, } 2}$ & $\lambda^{\text {max, 1 }}$ & $\lambda^{\text {max, 2 }}$ \\
\hline Neutral & 256 & 373 & 255 & 367 \\
Protonated & 275 & 450 & 268 & 439 \\
Monoanionic & 281 & 393 & 272 & 383 \\
\hline
\end{tabular}

149

150 The molar extinction coefficients is less for bromine derivative. At $\mathrm{pH}$ above 8.20 the 151 destruction of $\mathrm{BQR}$ is observed. For this reason the acid-base properties of bromoquercetin 152 were investigated in $\mathrm{pH}$ region from 2.0 to 7.3 , where occurring only first step of dissociation. 153 All raw spectroscopic data are given in the Supplementary Material (Tables S1-S6).
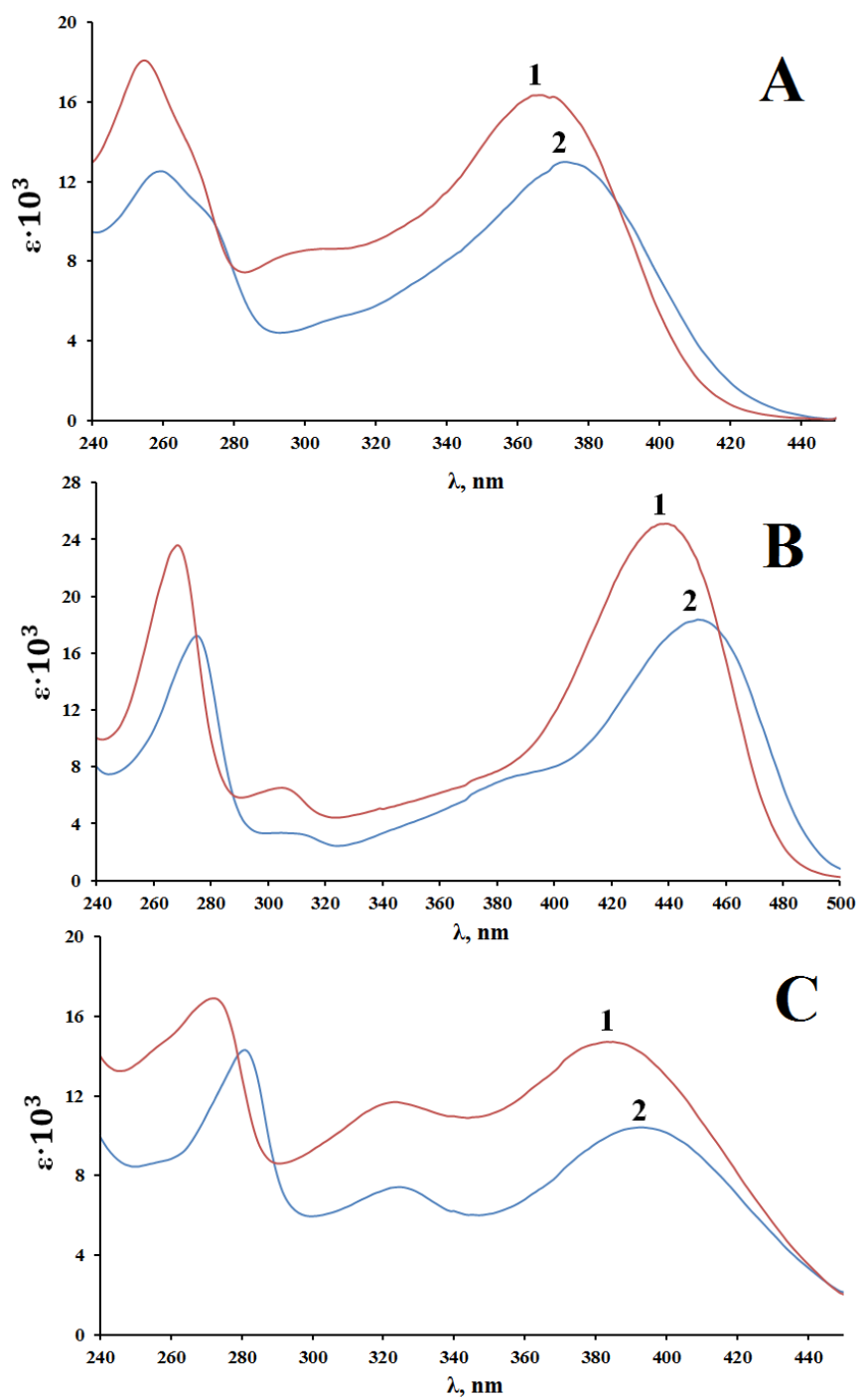

155 Fig. 1. The UV-vis spectra of different froms of quercetin(1) and 6-bromoquercetin(2):

156 neutral at $\mathrm{pH}=1(\mathrm{~A})$, protonated at $\mathrm{C}(\mathrm{HCl})>10 \mathrm{M}(\mathrm{B})$ and monoanionic $(\mathrm{C})$ at $\mathrm{pH}=8.0$. 
As the derivative of quercetin, 6-bromoquercetin exhibit property of a weak acid. Fig. 2

158 provides the spectral change of $\mathrm{BQR}$ as function of $\mathrm{pH}$. The presence of isosbestic points 159 reflects the transformation only one form in single product. As a background electrolyte was 160 utilized $\mathrm{NaClO}_{4}$. The slight absorption of phosphate-citrate buffer was take into account in 161 calculations of final values of $\mathrm{pK}_{\mathrm{a}}$. The obtained results of acid-base properties in $\mathrm{pH}$ region 162 are given at Table 2. The constant of dissociation was determine at three values of ionic 163 strength: $0.1,0.5$ and $1.0 \mathrm{M}$.

Table 2. The values of $\mathrm{pK}_{\mathrm{a}}$, extinctions of anionic and neutral form of $\mathrm{BQR}$

\begin{tabular}{|c|c|c|c|c|c|c|}
\hline $\mathrm{I}\left(\mathrm{NaClO}_{4}\right)$ & \multicolumn{2}{|c|}{0.1} & \multicolumn{2}{|c|}{0.5} & \multicolumn{2}{|c|}{1.0} \\
\hline$\lambda, \mathrm{nm}$ & 281 & 408 & 281 & 408 & 281 & 408 \\
\hline $\mathrm{pK}_{\mathrm{a}} \pm 0.02$ & 5.68 & 5.70 & 5.85 & 5.90 & 6.04 & 6.01 \\
\hline $\log \left(\varepsilon_{\mathrm{L}-}\right) \pm 0.01$ & 4.16 & 3.96 & 4.14 & 3.94 & 4.14 & 3.93 \\
\hline $\log \left(\varepsilon_{\mathrm{HL}}\right) \pm 0.01$ & 3.78 & 3.60 & 3.78 & 3.61 & 3.79 & 3.62 \\
\hline
\end{tabular}

166

This has been done in order to use these data in various conditions. For three values of 168 $\mathrm{pK}_{\mathrm{a}}$ the analysis of $\log (\mathrm{IR})$-pH relationship (eq. 2; Fig. S1) demonstrate the mono deprotonation 169 character of during process. The founded values of $\mathrm{pK}_{\mathrm{a}}$ of $\mathrm{BQR}$ lie from 5.68 to 6.04 170 logarithmic units. All these data characterize 6-bromoquercetin as more acidic ligand than 171 quercetin $(\mathrm{pKa}=7.20$ (Kopacz 2003)). This fact can be explain by polarizing effect inducted 172 by bromine atom: the appearance in molecular structure heavy halogen atom is increase of 173 electrostatic tension and weaken of $\mathrm{O}-\mathrm{H}$ bond.

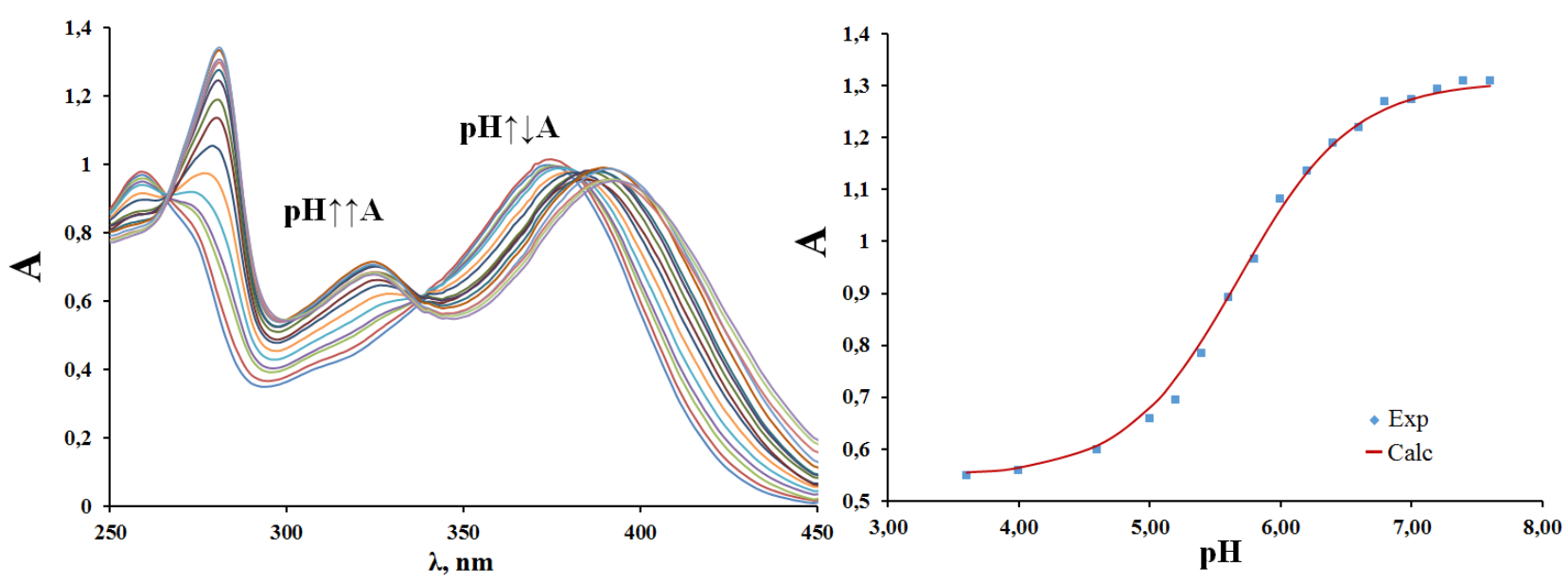

176 Fig. 2. The UV-Vis spectra and absorbance at $281 \mathrm{~nm}$ of 6-bromoquercetin at various values 177 of $\mathrm{pH} ; \mathrm{C}$ (bromoquercetin $)=9.14 \cdot 10^{-5} \mathrm{M}, \mathrm{I}=0.1 \mathrm{M}$. 
The treatment of acid-base properties in acidic media was perform in concentrated

79 hydrochloric solutions. Fig. 3 has shown a transformation of $\mathrm{BQR}$ spectra at increase of $\mathrm{HCl}$ 180 concentration. The calculations of protonation constant $\left(-\mathrm{pK}_{\mathrm{H}}\right)$ have been carried out for 2 181 wavelength -450 and $375 \mathrm{~nm}$. For both wavelength the assessment provides the equal values 182 of $-\mathrm{pK}_{\mathrm{H}}=3.50 \pm 0.03$ logarithmic units. An analogous value for quercetin is $2.30 \log$ units 183 (Kopacz 2003). Therefore, the reported value of - $\mathrm{pK}_{\mathrm{H}}$ describes this flavonoid as a weaker base 184 in acidic solution than quercetin. The $\mathrm{m}^{*}$ parameter (from eq. 3 ) or solvation coefficien $\mathrm{t}$ 185 (Hoyuelos et al. 2005) for this process is equal 0.97 \pm 0.04 . This coefficient depend on the 186 mechanism of protonation and nature of protonated atom. In this case $\left(\mathrm{m}^{*} \sim 1\right)$ it indicate that $187 \mathrm{H}_{2} \mathrm{~L}^{+}$form of $\mathrm{BQR}$ is small and not very polarizable molecule (Hoyuelos et al. 2005).
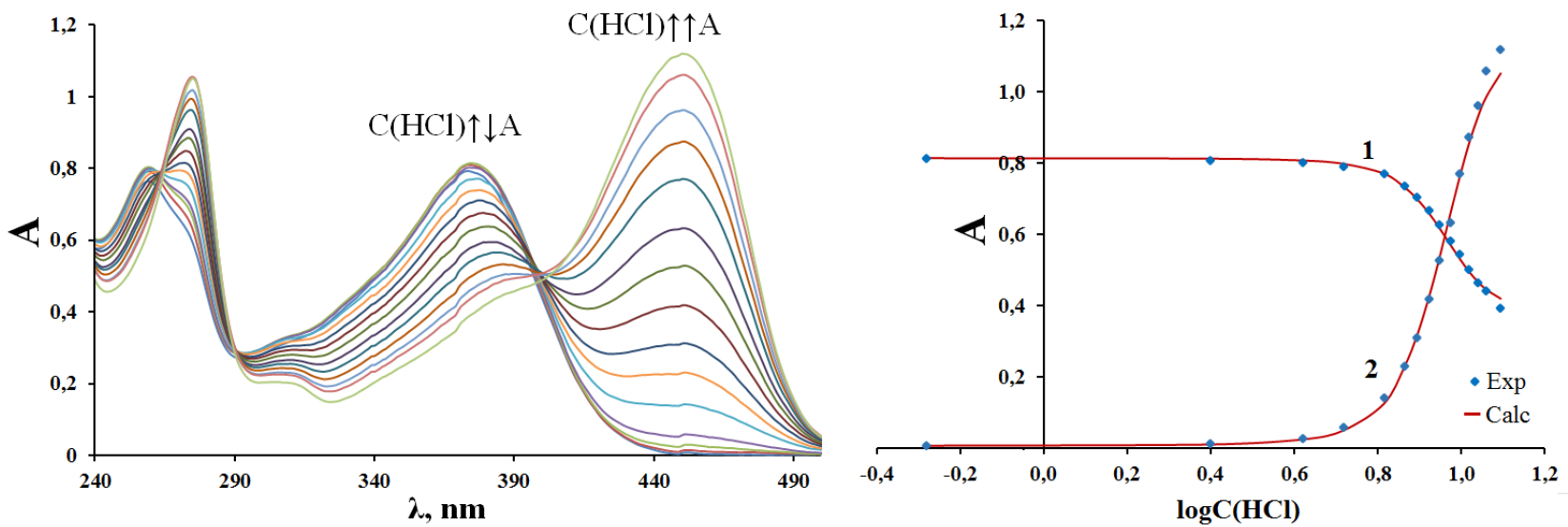

Fig. 1. The UV-vis scanning spectra of $B Q R$ obtained at various concentration of $\mathrm{HCl}$ and 191 absorbance $(1-375 \mathrm{~nm} ; 2-450 \mathrm{~nm})$ as a function of $\log (\mathrm{C}(\mathrm{HCl})) ; \mathrm{C}($ bromoquercetin $)=$ $1926.09 \cdot 10^{-5} \mathrm{M}$.

193

194 3.1 The DFT study

195 The dissociation and protonation of neutral form of BQR can lead to the appearance of several 196 tautomers. Each of $\mathrm{OH}$ group in this molecule can dissociate or be protonated. The all possible 197 isomers of anionic and protonated forms are collected at Scheme 2. 
<smiles>Nc1cc(-c2oc3cc(O)c(Br)c(O)c3c(=O)c2O)ccc1O</smiles><smiles>[Li]</smiles><smiles>[N-]=[N+]=[N-]</smiles><smiles>CCOCC=Cc1oc2cc(O)c(Br)c(O)c2c(=O)c1O</smiles><smiles></smiles><smiles>[R7]OC(C(=O)c1ccc(O)c(O)c1)=C(O)c1c(O)cc(O)c(Br)c1O</smiles><smiles></smiles>

200 Scheme 2. The anionic $(n=0)$ and protonated $(n=2 ; P 1$ and $P 2)$ tautomers of $B Q R$

201

202 The tautomers P1 and P2 are possible only for protonated form. For the estimate of 203 thermodynamic stability of these structures the absolute and relative energies were calculated 204 (Table 3) at level cc-pVDZ/DFT/PBE0/SMD. All assessments demonstrate that acid-base 205 processes relate with 4-carbonyl and 5-hydroxyl groups. The most stable anionic form is the 206 isomer with negative charge on the 5-hydroxyl position (N1). The domination form of 207 protonated bromoquercetin is the cation $\mathrm{P} 1$ with one more proton atom on the 4-carbonyl group.

Table 3. The calculated absolute (a.u.) and relative $\left(\mathrm{kJ} \cdot \mathrm{mol}^{-1}\right)$ energies of $\mathrm{BQR}$ tautomers

\begin{tabular}{ccccc}
\hline & \multicolumn{2}{c}{ Protonated form $(\mathrm{n}=2)$} & \multicolumn{2}{c}{ Anionic form $(\mathrm{n}=0)$} \\
Tautomer & Absolute & Relative & Absolute & Relative \\
& energy & energy & energy & energy \\
\hline N1 & -3676.724254 & 92.19 & -3675.946043 & 0.00 \\
N2 & -3676.740029 & 50.77 & -3675.931125 & 39.17 \\
N3 & -3676.740148 & 50.46 & -3675.931271 & 38.78 \\
N4 & -3676.747360 & 31.53 & -3675.922961 & 60.60 \\
N5 & -3676.737160 & 58.31 & -3675.937402 & 22.69 \\
P1 & -3676.759367 & 0.00 & & \\
P2 & -3676.711874 & 124.69 & & \\
\hline
\end{tabular}


212 Now, the quantitative analysis of the Lowdin's charges can help to explain the difference of 213 acid-base properties between quercetin and BQR. The charge of O-atom of 5-hydroxyl group 214 is -0.304 and -0.272 for quercetin and bromoquercetin, respectively. The charge of hydrogen is 215 the same for both cases. Thus, bromine to decrease of negative charge on oxygen atom and 216 reinforces the repulsion between $\mathrm{H}$ and $\mathrm{O}$ that lead to high acidity. Analogous reasons suited 217 to protonation activates: the charge of 4-carbonyl oxygen is high for BQR $(-0.291)$ than for 218 quercetin (-0.307) and electrostatic bonding $\mathrm{O}-\mathrm{H}$ is durable for quercetin.

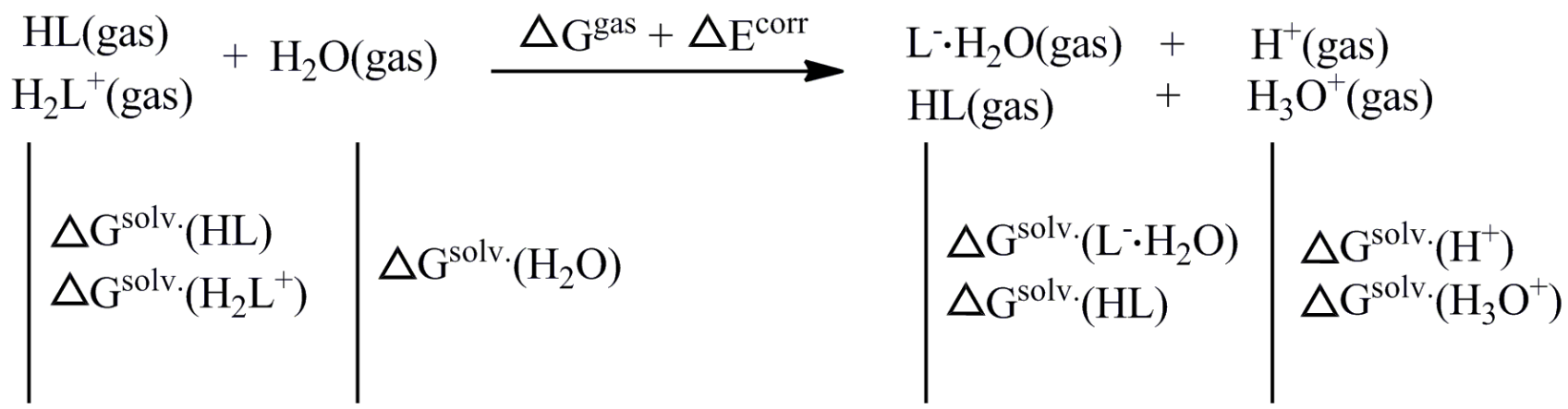

$\begin{gathered}\mathrm{HL} \text { (solv. }) \\ \mathrm{H}_{2} \mathrm{~L}^{+} \text {(solv.) }\end{gathered}+\mathrm{H}_{2} \mathrm{O}($ solv. $)$

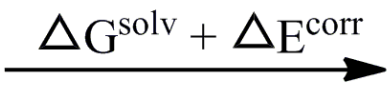

$\mathrm{L}^{-} \cdot \mathrm{H}_{2} \mathrm{O}($ solv. $)+\mathrm{H}^{+}$(solv.)

$\mathrm{HL}$ (solv.) $+\mathrm{H}_{3} \mathrm{O}^{+}$(solv.)

Scheme 3. The thermodynamic cycle for calculate $\mathrm{pK}_{\mathrm{a}}^{\text {calc. }}$ and $\mathrm{pK}_{\mathrm{H}}{ }^{\text {calc. }}$
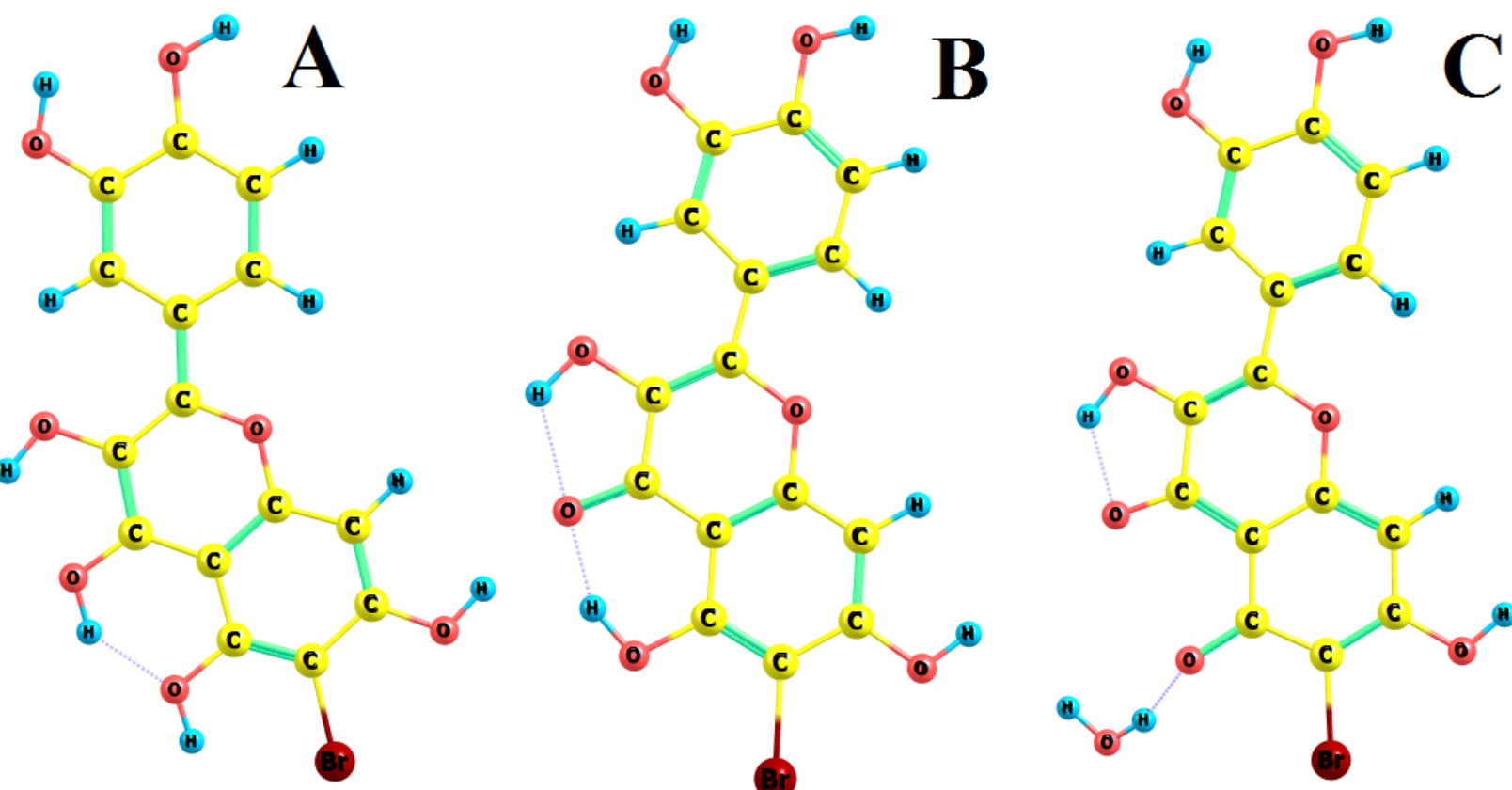

Fig. 4. The optimization geometry of protonated (A), neutral (B) and anionic (C) forms.
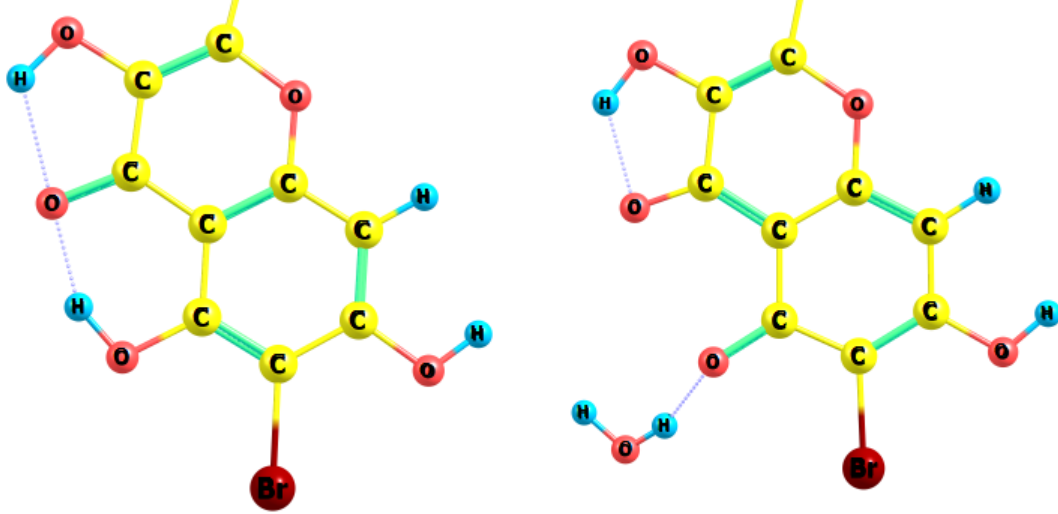
For search of optimal DFT method to describe thermodinamic results ab initio 228 calculations have been produced. The thermodynamic cycle showed at Scheme 3 was used for 229 computation protocol. The obtaining of $\mathrm{pK}_{\mathrm{a}}{ }^{\text {calc. }}$ and $\mathrm{pK}_{\mathrm{H}}{ }^{\text {calc. }}$ has been carried out at level cc$230 \mathrm{pVDZ} / \mathrm{DFT} / \mathrm{SMD}$ with using seven density functional. The cc-pVDZ has established itself as 231 usable for estimate of equilibrium processes of heterocyclic compounds (Lutoshkin and 232 Kazachenko 2017). The functionals from minesota family, TPSS group and LYP-class were 233 tested in this work. This choice was based on the wide using of these functionals for calculate 234 of various equilibrium processes (Banerjee and Bhanja 2018). Guided by theoretical work 235 (Bishnu and Schlegel 2016) the explicit water molecule was applied for compilation of $\mathrm{pKa}^{\text {calc. }}$. 236 The optimization geometry of studied species demonstrated at Fig. 4. The findings of estimation 237 are given at Table 4. In our case, the better approximation (for dissociation process) provides 238 functional M06-HF with 100\% of Hartree-Fock exchange. PBE0 demonstrate the best approach 239 for $\mathrm{pK}_{\mathrm{a}}$. All of other functionals gives grater discrepancy with experimental data. 240

241 Table 4. The results of quantum-chemical simulation.

\begin{tabular}{|c|c|c|c|c|}
\hline \multirow{2}{*}{$\begin{array}{c}\text { Density } \\
\text { Functional }\end{array}$} & \multicolumn{4}{|c|}{ Dissociation process } \\
\hline & $\Delta \mathrm{G}^{\mathrm{gas}}+\Delta \mathrm{G}^{\mathrm{solv} .}, \mathrm{kJ} / \mathrm{mol}$ & $\Delta \mathrm{E}^{\mathrm{ZPE}}$ & $\mathrm{pK}_{\mathrm{a}}(\mathrm{calc})$ & $\mathrm{pK}_{\mathrm{a}}(\exp )$ \\
\hline PBE0 & 91.23 & -33.99 & 9.66 & \\
\hline revTPSS & 104.79 & -32.03 & 12.39 & \\
\hline M06-L & 99.37 & -34.05 & 11.08 & \\
\hline M06 & 82.97 & -33.94 & 8.25 & 5.86 \\
\hline M06-2X & 82.71 & -34.30 & 8.12 & \\
\hline M06-HF & 65.30 & -33.86 & 5.15 & \\
\hline CAM-B3LYP & 117.59 & -33.56 & 9.74 & \\
\hline Density & \multicolumn{4}{|c|}{ Protonation process } \\
\hline Functional & $\Delta \mathrm{G}^{\mathrm{gas}}+\Delta \mathrm{G}^{\mathrm{solv} .}, \mathrm{kJ} / \mathrm{mol}$ & $\Delta \mathrm{E}^{\mathrm{ZPE}}$ & $-p K_{H}($ calc $)$ & $-p K_{H}(\exp )$ \\
\hline PBE0 & -27.81 & 10.84 & 3.33 & \\
\hline revTPSS & -90.19 & 2.20 & 15.77 & \\
\hline M06-L & 30.08 & 8.42 & -6.39 & \\
\hline M06 & 31.35 & 7.70 & -6.48 & 3.50 \\
\hline M06-2X & 25.39 & 7.91 & -5.47 & \\
\hline M06-HF & -81.32 & 7.83 & 13.23 & \\
\hline CAM-B3LYP & 26.81 & -12.60 & -2.13 & \\
\hline
\end{tabular}


243 3.3 Stability of Lanthanide complexes

244 Bromoquercetin, as well as quercetin, is effective complexing agent for trivalent lanthanides in 245 solution. All measurements were completed in acetate buffer at ionic strength $0.5 \mathrm{M}$. The 246 working $\mathrm{pH}$ range lie from 4.40 to 5.40 . Due to the studied flavonoid has small aqueous 247 solubility, the determination of stability constants has been performed at constant concentration 248 of ligand in each series. The various concentration of lanthanides was taken in excess $249(\mathrm{C}(\mathrm{M})>\mathrm{C}(\mathrm{L}))$ for eliminating the possibility of the formation of poly-ligand complexes $\mathrm{M}_{\mathrm{n}} \mathrm{L}_{\mathrm{m}}$. 250 In Fig. 5, the BQR spectra under different concentration of ytterbium(III) are shown. For BQR$251 \mathrm{Ln}(\mathrm{III})$ system $\Delta \mathrm{A}^{\mathrm{max}}$ has a constant position at $430 \mathrm{~nm}$ (Fig. S2) and depends only from metal 252 concentration. This facts, significant excess of $\mathrm{Ln}^{3+}$ and existence of a isopiestic points indicates 253 about formation of one products - 1:1 complex ML. The similar reasons can be applied for all 254 systems. The received data of equilibrium parameters for complexation are given at Table 3.
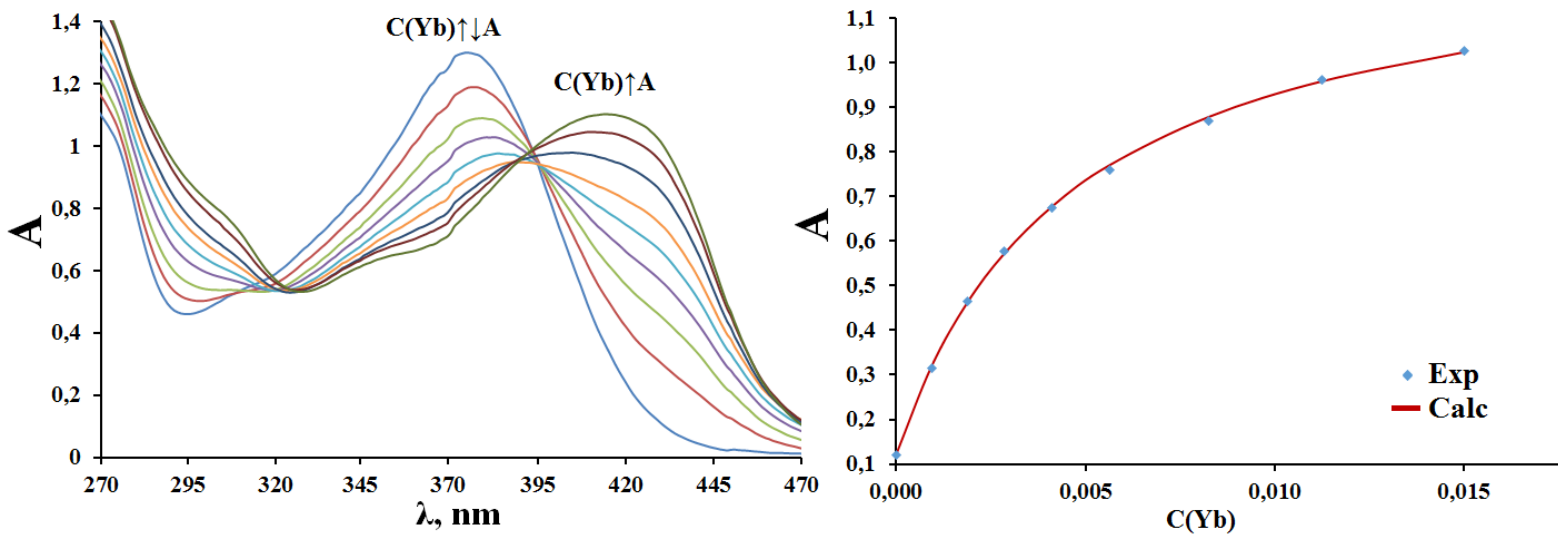

Fig. 5. The UV-Vis spectra and absorbance at single wavelength (429 nm) for $\mathrm{Yb}(\mathrm{III})-\mathrm{BQR}$ system; $\mathrm{C}($ bromoquercetin $)=9.14 \cdot 10^{-5} \mathrm{M} ; \mathrm{pH}=4.4, \mathrm{I}=0.5 \mathrm{M}(\mathrm{NaClO} 4)$.

To confirm of chosen coordination model the stability constants for some of metals $261\left(\mathrm{Yb}^{3+}\right.$ and $\left.\mathrm{Er}^{3+}\right)$ were obtain for three values of $\mathrm{pH}$. The linear relationship of $\mathrm{pH}-\log \mathrm{K}$ and 262 slope coefficient $\approx 1$ testify to monodeprotonation of ligand upon complexation process. 263 Furthermore, the formation of complexes with $\mathrm{OH}^{-}$and acetate ions is typical for all rare earth 264 metal. To take into account of side reactions the following equations were fitted:

$$
\alpha_{L}=1+\sum K_{H}\left[H^{+}\right] \text {, }
$$


270 where $\mathrm{K}_{\mathrm{H}}=1 / \mathrm{Ka}$ was determine in $\mathrm{pH}$ region. The constants of adverse reaction $(\beta \mathrm{n})$

Table 5. Conditional (K'), "true" (K) stability constants and value of extinction at $429 \mathrm{~nm}$ for BQR-Ln(III) systems

\begin{tabular}{ccccc}
\hline $\mathrm{Ln}(\mathrm{III})$ & $\mathrm{pH} \pm 0.01$ & $\log \mathrm{K}^{\prime} \pm 0.01$ & $\log \varepsilon^{429} \pm 0.03$ & $\log \pm 0.05$ \\
\hline $\mathrm{Ce}$ & 5.20 & 2.18 & 4.14 & 4.04 \\
$\mathrm{Pr}$ & 5.20 & 2.31 & 4.14 & 4.83 \\
$\mathrm{Nd}$ & 5.20 & 2.13 & 4.17 & 4.27 \\
$\mathrm{Sm}$ & 5.20 & 2.59 & 4.12 & 4.91 \\
$\mathrm{Eu}$ & 5.40 & 2.72 & 4.13 & 4.83 \\
$\mathrm{Gd}$ & 5.20 & 2.64 & 4.14 & 4.82 \\
$\mathrm{~Tb}$ & 4.60 & 2.43 & 4.15 & 5.50 \\
$\mathrm{Dy}$ & 4.60 & 2.24 & 4.16 & 5.27 \\
& 4.40 & 2.24 & 4.14 & 5.43 \\
$\mathrm{Er}$ & 4.60 & 2.40 & 4.18 & 5.40 \\
& 4.80 & 2.65 & 4.12 & 5.47 \\
$\mathrm{Tm}$ & 4.60 & 2.26 & 4.19 & 5.27 \\
& 4.20 & 2.12 & 4.14 & 6.40 \\
$\mathrm{Yb}$ & 4.40 & 2.34 & 4.15 & 6.42 \\
& 4.60 & 2.58 & 4.11 & 6.48 \\
$\mathrm{Lu}$ & 4.60 & 2.70 & 4.14 & 5.77 \\
\hline
\end{tabular}

The obtained values of $\log \mathrm{K}$ lie in region 4.0-6.5 logarithmic units. The stability 279 constants follow the order: $\mathrm{Ce}<\mathrm{Nd}<\mathrm{Gd} \approx \mathrm{Eu} \approx \operatorname{Pr}<\mathrm{Sm}<\mathrm{Dy} \approx \mathrm{Tm}<\mathrm{Er}<\mathrm{Tb}<\mathrm{Lu}<\mathrm{Yb}$. Fig. 6 (A) 280 illustrate $\operatorname{Ln}(\mathrm{III})-\log \mathrm{K}$ relationship. This shape of $\log \mathrm{K}-\mathrm{Ln}(\mathrm{III})$ curve indicate about general 281 ionic nature of the bonding (Choppin 1983).

282 The similarity of spectral changes and molecular structure quercetin and BQR allows to 283 propose the same coordination of their lanthanides complexes (via 3-hydroxyl-4-carbonyl 284 group (Woźnicka et al. 2017; Lutoshkin et al. 2018)). Fig. 6(A) demonstrate that lanthanides 285 complexes of BQR by 1-2 order weaker than $\operatorname{Ln}(\mathrm{III})$-quercetin complexes. Like in the case of 286 dissociation, this can be attributed to general electrostatic of molecule: the bromine atom 
287 decrease the electronic density on the of 3-hydroxyl group and increase of decoupling between $288 \mathrm{O}$ atom of chelate group and $\mathrm{Ln}^{3+}$.
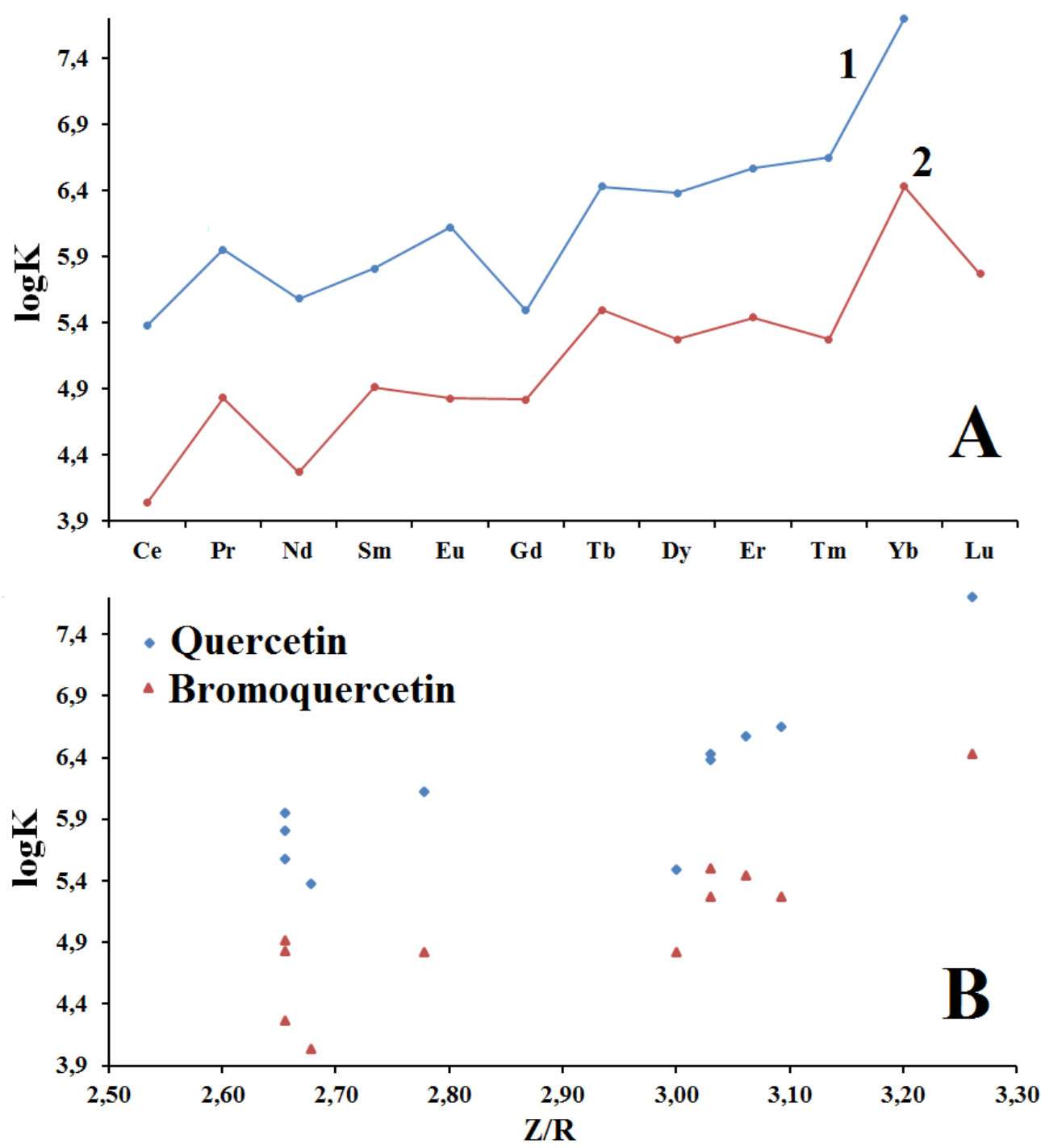

Fig. 6. The $\log K-\operatorname{Ln}(\mathrm{III})$ curves (A) for quercetin (1) and bromoquercetin (2) and $\log \mathrm{K}-\mathrm{Z} / \mathrm{R}$ points (B).

The distribution of points on the $\log \mathrm{K}-\mathrm{Z} / \mathrm{R}$ plot is presented on Fig. 6 (B) has shown 295 that (as in the case of quercetin) all metals separated by two group: Ce-Eu and Gd-Lu. The 296 second group of lanthanides show a weak correlation with ionic potential. This suggests that 297 electrostatic interaction for these metals a slightly stronger than for Ce-Eu group. Perhaps, the 298 separation can be explained by the sharp rise of covalence contribution in Gd-Lu complexes 299 and participation of the $6 \mathrm{~d}$ and/or $7 \mathrm{~s}$ orbitals rather than $\mathrm{f}$ orbitals in the bonding (Choppin and 300 Rizkalla 1994). 
The thermodynamic parameters of 6-bromoquercetin have been described in solution 305 using electronic absorption spectroscopy. The spectral, acid-base and complexing properties 306 were studied at various ionic strength and acidity. Bromoquercetin is a stronger acid $\left(\mathrm{pK}_{\mathrm{a}}=5.68\right.$ $3076.04)$ and weak base $\left(-\mathrm{pK}_{\mathrm{H}}=3.50\right)$ than quercetin.

At level cc-pVDZ/DFT/PBE0/SMD were suggests the dominated forms (neutral, 309 monoanionic and protonated) of $\mathrm{BQR}$ and explain their acidity. Seven density functionals 310 (PBE0, CAM-B3LYP, M06, M06-L, M06-2X, M06-HF and revTPSS) were tested for search 311 an optimal theoretical pathways to describe of obtained data. M06-HF and PBE0 functionals 312 provide the better approximation for dissociation and protonation processes, respectively. The 313 computation protocol with explicit water and specific solvation has been allows to reproduce 314 experimental values with discrepancies \pm 0.5 logarithmic units.

The investigation of 1:1 complexes of bromoquercetin and 12 lanthanides has been 316 perform at wide range of $\mathrm{pH}$ at constant ionic strength $(\mathrm{I}=0.5 \mathrm{M}) .16$ conditionals and 12 "true" 317 equilibrium stability constants were obtained. The received stability constants lie from 4.04 to 3186.46 logarithmic units and increase in the following order: $319 \mathrm{Ce}<\mathrm{Nd}<\mathrm{Gd} \approx \mathrm{Eu} \approx \operatorname{Pr}<\mathrm{Sm}<\mathrm{Dy} \approx \mathrm{Tm}<\mathrm{Er}<\mathrm{Tb}<\mathrm{Lu}<\mathrm{Yb}$. The low efficiency of $\mathrm{BQR}$ as 320 complexation agent (compared to quercetin) was explain by the distribution of charges in 321 optimization structure.

322

\section{References}

Adamo C, Barone V (1999) Toward reliable density functional methods without adjustable parameters: The PBE0 model. J Chem Phys 110:6158-6170. doi: 10.1063/1.478522

327 Banerjee S, Bhanja SK, Chattopadhyay PK (2018) Quantum chemical predictions of aqueous $328 \mathrm{pK}_{\mathrm{a}}$ values for $\mathrm{OH}$ groups of some $\alpha$-hydroxycarboxylic acids based on ab initio and DFT 329 calculations. Computational and Theoretical Chemistry 1125:29-38.

331 Bishnu T, Schlegel HB (2016) Density Functional Theory Calculation of pKa's of Thiols in 332 Aqueous Solution Using Explicit Water Molecules and the Polarizable Continuum Model. J 333 Phys Chem A 120:5726-5735. doi:10.1021/acs.jpca.6b05040 
334 Bryantsev VS, Mamadou SD, Goddard III WA (2008) Calculation of solvation free energies of 335 charged solutes using mixed cluster/continuum models. J Phys Chem B 112:9709-9719. 336 doi:10.1021/jp810292n.

337

338 Choppin GR (1983) Comparison of the solution chemistry of the actinides and lanthanides. 339 Journal of the Less-Common Metals 93:323-330. doi:10.1016/0022-5088(83)90177-7 340

341 Choppin GR, Rizkalla EN (1994) Handbook on the Physics and Chemistry of Rare Earths, 42 Solution chemistry of actinides and lanthanides, Elsevier Science B.V., New York 343

344 Cox $\mathrm{R}$ (1981) The excess acidity of aqueous $\mathrm{HCl}$ and $\mathrm{HBr}$ media. An improved method for the 345 calculation of X-functions and H. Can J Chem 59:2023-2028. doi: 10.1139/v81-306 346

Cox R (1983) Acidity functions: an update. Can J Chem 61:2225-2229. doi: 10.1139/v83-388 348 Cushnie TP, Lamb AJ (2005) Antimicrobial activity of flavonoids. Int J Antimicrob Agents 349 26:343-356. doi: 10.1016/j.ijantimicag.2005.09.002

350 doi:10.1016/j.comptc.2017.12.011

351

352 Dunning JrTH (1989) Gaussian basis sets for use in correlated molecular calculations. I. The 353 atoms boron through neon and hydrogen. J Chem Phys 90:1007-1023. doi: 10.1063/1.456153 354

355 Grebenyuk SA, Perepichka IF, Popov AF (2002) Evaluation of the parameters of 1:1 charge 356 transfer complexes from spectrophotometric data by non-linear numerical method. 357 Spectrochim. Acta Part A 58:2913-2923. doi: 10.1016/S1386-1425(02)00035-5 358 359 Grimme S, Antony J, Ehrlich S, Krieg HA (2010) A consistent and accurate ab initio 360 parametrization of density functional dispersion correction (DFT-D) for the 94 elements $\mathrm{H}-\mathrm{Pu}$. 361 J Chem Phys 132:154104. doi: 10.1063/1.3382344.

363 Hoyuelos FJ, Garcia B, Ibeas S, Munoz MS, Navarro AM, Penacoba I, Leal JM (2005) 364 Protonation Sites of Indoles and Benzoylindoles. Eur J Org Chem 6:1161-1171. 365 doi:10.1002/ejoc.200400434 
67 Kasprzak MM, Erxleben A, Ochocki J (2015) Properties and applications of flavonoid metal 368 complexes. RSC Advance 5:45853-45877. doi: 10.1039/C5RA05069C

Kessler M, Ubeaud G, Jung L (2003) Anti- and pro-oxidant activity of rutin and quercetin derivatives. J Pharm Pharmacol 55:131-142. doi: 10.1211/002235702559

Kopacz M (2003) Quercetin- and Morinsulfonates as Analytical Reagents. Journal of Analytical Chemistry 58:225-229. doi: 10.1023/A:1022630319311

6 Le Marchand L (2002) Cancer preventive effects of flavonoids--a review. Biomed 377 Pharmacother 56:296-301. doi : 10.1016/S0753-3322(02)00186-5

Leggett DJ (1985) Computational Methods for the Determination of Formation Constants, 380 Plenum Press, New York

381 Lutoshkin MA, Kazachenko AS (2017) Assessment of various density functionals and 382 solvation models to describe acid-base, spectral and complexing properties of thiobarbituric 383 and barbituric acids in aqueous solution. Journal of Computational Methods in Sciences and 384 Engineering 17:1-13. doi:10.3233/JCM-170745

Lutoshkin MA, Petrov AI, Kazachenko AS, Kuznetsov BN, Levdansky VA (2018) Complexation of rare earth metals by quercetin and quercetin-5' -sulfonic acid in acidic aqueous 388 solution. Main Group Chemistry 17:17-25. doi: 10.3233/MGC-180253

390 M Samsonowicz, Regulska E (2017) Spectroscopic study of molecular structure, antioxidant 391 activity and biological effects of metal hydroxyflavonol complexes. Spectrochim Acta A Mol 392 Biomol Spectrosc 173:757-771. doi: 10.1016/j.saa.2016.10.031 393 394 Manach C, Morand C, Crespy V, Demigne C, Texier O, Régérat F, Rémésy C (1998) Quercetin 395 is recovered in human plasma as conjugated derivatives which retain antioxidant properties. 396 FEBS Lett 426:331-336. doi: 10.1016/S0014-5793(98)00367-6

398 Marenich AV, Cramer CJ, Truhlar DG (2009) Universal solvation model based on solute 399 electron density and on a continuum model of the solvent defined by the bulk dielectric constant 400 and atomic surface tensions. J Phys Chem 113:6378-6396. doi: 10.1021/jp810292n. 
402 Nagimova AD, Zhusupova GE, Erzhanova MS (1996) Synthesis of biologically active bromine 403 derivatives of quercetin. Chemistry of Natural Compounds 32:695-697.

404 Panche AN, Diwan AD, Chandra SR (2016) Flavonoids: an overview. J Nutr Sci 5:1-15. 405 doi:10.1017/jns.2016.41

406

407 Perdew JP, Ruzsinszky A, Csonka GI, Constantin LA (2011) Workhorse Semilocal Density 408 Functional for Condensed Matter Physics and Quantum Chemistry. Phys Rev Lett 106:179902409 179906. doi: 10.1103/PhysRevLett.103.026403

410

Schmidt MW (1993) General atomic and molecular electronic structure system. Comput Chem 14:1347-1363. doi: 10.1002/jcc.540141112

413

414 Sotnikova R, Nosalova V, Navarova J (2013) Efficacy of quercetin derivatives in prevention of 415 ulcerative colitis in rats. Interdiscip Toxicol 6:9-12. doi: 10.2478/intox-2013-0002

416

417 Srinivas K, King JW, Howard LR, Monrad JK (2010) Solubility and solution thermodynamic 418 properties of quercetin and quercetin dihydrate in subcritical water. J Food Eng 100:208-218. 419 doi: 10.1016/j.jfoodeng.2010.04.001

420

421 Tiwari S, Ghosh KK (2010) Mixed micellization properties of cationic monomeric and gemini 422 surfactants. J Chem Eng Data 55:4162-4167. doi: 10.1021/je100113r

423

Vinayagam R, Xu B (2015) Antidiabetic properties of dietary flavonoids: a cellular mechanism review. Nutrition \& Metabolism 12 :60-80. doi: 10.1186/s12986-015-0057-7

426

Vukovic S, Hay BP, Bryantsev VS (2015) Predicting Stability Constants for Uranyl Complexes Using Density Functional Theory. Theor Inorg Chem 54:3995-4001. doi:10.1021/acs.inorgchem.5b00264

430

431 Woźnicka E, Zapała L, Pieniążek E, Kosińska M, Ciszkowicz E, Lecka-Szlachta K, Pusz J, 432 Maciołek U, Dronka J (2017) Synthesis, characterization and antibacterial studies of Tm(III), $433 \mathrm{Yb}(\mathrm{III})$ and Lu(III) complexes of morin. J Coord Chem 70:1451-1463. 434 doi:10.1080/00958972.2017.1291935 
435 Yanai T, Tew DP, Handyb NC (2004) A new hybrid exchange-correlation functional using the 436 Coulomb-attenuating method (CAM-B3LYP). Chemical Physics Letters 393:51-57. doi: 437 10.1016/j.cplett.2004.06.011

438

439 Zhao Y, Truhlar DG (2008) The M06 suite of density functionals for main group 440 thermochemistry, thermochemical kinetics, noncovalent interactions, excited states, and 441 transition elements: two new functionals and systematic testing of four M06-class functionals 442 and 12 other functionals. Theor Chem Account 120:215-241. doi: 10.1007/s00214-007-0310$443 \mathrm{X}$.

444 
Table 5. Conditional (K'), "true" $(\mathrm{K})$ stability constants and value of extinction at $429 \mathrm{~nm}$ for BQR-Ln(III) systems

\begin{tabular}{ccccc}
\hline $\mathrm{Ln}(\mathrm{III})$ & $\mathrm{pH} \pm 0.01$ & $\log \mathrm{K}^{\prime} \pm 0.01$ & $\log \varepsilon^{429} \pm 0.03$ & $\operatorname{logK} \pm 0.05$ \\
\hline $\mathrm{Ce}$ & 5.20 & 2.18 & 4.14 & 4.04 \\
$\mathrm{Pr}$ & 5.20 & 2.31 & 4.14 & 4.83 \\
$\mathrm{Nd}$ & 5.20 & 2.13 & 4.17 & 4.27 \\
$\mathrm{Sm}$ & 5.20 & 2.59 & 4.12 & 4.91 \\
$\mathrm{Eu}$ & 5.40 & 2.72 & 4.13 & 4.83 \\
$\mathrm{Gd}$ & 5.20 & 2.64 & 4.14 & 4.82 \\
$\mathrm{~Tb}$ & 4.60 & 2.43 & 4.15 & 5.50 \\
$\mathrm{Dy}$ & 4.60 & 2.24 & 4.16 & 5.27 \\
& 4.40 & 2.24 & 4.14 & 5.43 \\
$\mathrm{Er}$ & 4.60 & 2.40 & 4.18 & 5.40 \\
& 4.80 & 2.65 & 4.12 & 5.47 \\
$\mathrm{Tm}$ & 4.60 & 2.26 & 4.19 & 5.27 \\
& 4.20 & 2.12 & 4.14 & 6.40 \\
$\mathrm{Yb}$ & 4.40 & 2.34 & 4.15 & 6.42 \\
$\mathrm{Lu}$ & 4.60 & 2.58 & 4.11 & 6.48 \\
& 4.60 & 2.70 & 4.14 & 5.77
\end{tabular}


Table 4. The results of quantum-chemical simulation.

\begin{tabular}{ccccc}
\hline Density & \multicolumn{4}{c}{ Dissociation process } \\
Functional & $\Delta \mathrm{G}^{\text {gas }}+\Delta \mathrm{G}^{\text {solv. }}, \mathrm{kJ} / \mathrm{mol}$ & $\Delta \mathrm{E}^{\mathrm{ZPE}}$ & $\mathrm{pK}_{\mathrm{a}}(\mathrm{calc})$ & $\mathrm{pK}_{\mathrm{a}}(\mathrm{exp})$ \\
\hline PBE0 & 91.23 & -33.99 & 9.66 & \\
revTPSS & 104.79 & -32.03 & 12.39 & \\
M06-L & 99.37 & -34.05 & 11.08 & \\
M06 & 82.97 & -33.94 & 8.25 & 5.86 \\
M06-2X & 82.71 & -34.30 & 8.12 & \\
M06-HF & 65.30 & -33.86 & 5.15 & \\
CAM-B3LYP & 117.59 & -33.56 & 9.74 & \\
\hline Density & & Protonation process & \\
Functional & $\Delta \mathrm{G}^{\text {gas }}+\Delta \mathrm{G}^{\text {solv. }}, \mathrm{kJ} / \mathrm{mol}$ & $\Delta \mathrm{E}^{\mathrm{ZPE}}$ & $-\mathrm{pK} \mathrm{H}(\mathrm{calc})$ & $-\mathrm{pK} \mathrm{H}(\mathrm{exp})$ \\
\hline PBE0 & -27.81 & 10.84 & 3.33 & \\
revTPSS & -90.19 & 2.20 & 15.77 & \\
M06-L & 30.08 & 8.42 & -6.39 & \\
M06 & 31.35 & 7.70 & -6.48 & 3.50 \\
M06-2X & 25.39 & 7.91 & -5.47 & \\
M06-HF & -81.32 & 7.83 & 13.23 & \\
CAM-B3LYP & 26.81 & -12.60 & -2.13 & \\
\hline
\end{tabular}


Table 3. The calculated absolute (a.u.) and relative $\left(\mathrm{kJ} \cdot \mathrm{mol}^{-1}\right)$ energies of $\mathrm{BQR}$ tautomers

\begin{tabular}{ccccc}
\hline & \multicolumn{2}{c}{ Protonated form $(\mathrm{n}=2)$} & \multicolumn{2}{c}{ Anionic form $(\mathrm{n}=0)$} \\
Tautomer & Absolute & Relative & Absolute & Relative \\
& energy & energy & energy & energy \\
\hline N1 & -3676.724254 & 92.19 & -3675.946043 & 0.00 \\
N2 & -3676.740029 & 50.77 & -3675.931125 & 39.17 \\
N3 & -3676.740148 & 50.46 & -3675.931271 & 38.78 \\
N4 & -3676.747360 & 31.53 & -3675.922961 & 60.60 \\
N5 & -3676.737160 & 58.31 & -3675.937402 & 22.69 \\
P1 & -3676.759367 & 0.00 & & \\
P2 & -3676.711874 & 124.69 & & \\
\hline
\end{tabular}


Table 2. The values of $\mathrm{pK}_{\mathrm{a}}$, extinctions of anionic and neutral form of $\mathrm{BQR}$

\begin{tabular}{ccccccc}
\hline $\mathrm{I}\left(\mathrm{NaClO}_{4}\right)$ & \multicolumn{2}{c}{0.1} & \multicolumn{2}{c}{0.5} & \multicolumn{2}{c}{1.0} \\
\hline$\lambda, \mathrm{nm}$ & 281 & 408 & 281 & 408 & 281 & 408 \\
$\mathrm{pK}_{\mathrm{a}} \pm 0.02$ & 5.68 & 5.70 & 5.85 & 5.90 & 6.04 & 6.01 \\
$\log \left(\varepsilon_{\mathrm{L}-}\right) \pm 0.01$ & 4.16 & 3.96 & 4.14 & 3.94 & 4.14 & 3.93 \\
$\log \left(\varepsilon_{\mathrm{HL}}\right) \pm 0.01$ & 3.78 & 3.60 & 3.78 & 3.61 & 3.79 & 3.62 \\
\hline
\end{tabular}


Table 1. The values of wavelength $(\mathrm{nm})$ of main absorbance peaks of BQR and quercetin

\begin{tabular}{ccccc}
\hline \multirow{2}{*}{ Form } & \multicolumn{2}{c}{ 6-Bromoquercetin } & \multicolumn{2}{c}{ Quercetin } \\
& $\lambda^{\text {max, 1 }}$ & $\lambda^{\text {max, 2 }}$ & $\lambda^{\text {max, 1 }}$ & $\lambda^{\text {max, 2 }}$ \\
\hline Neutral & 256 & 373 & 255 & 367 \\
Protonated & 275 & 450 & 268 & 439 \\
Monoanionic & 281 & 393 & 272 & 383 \\
\hline
\end{tabular}



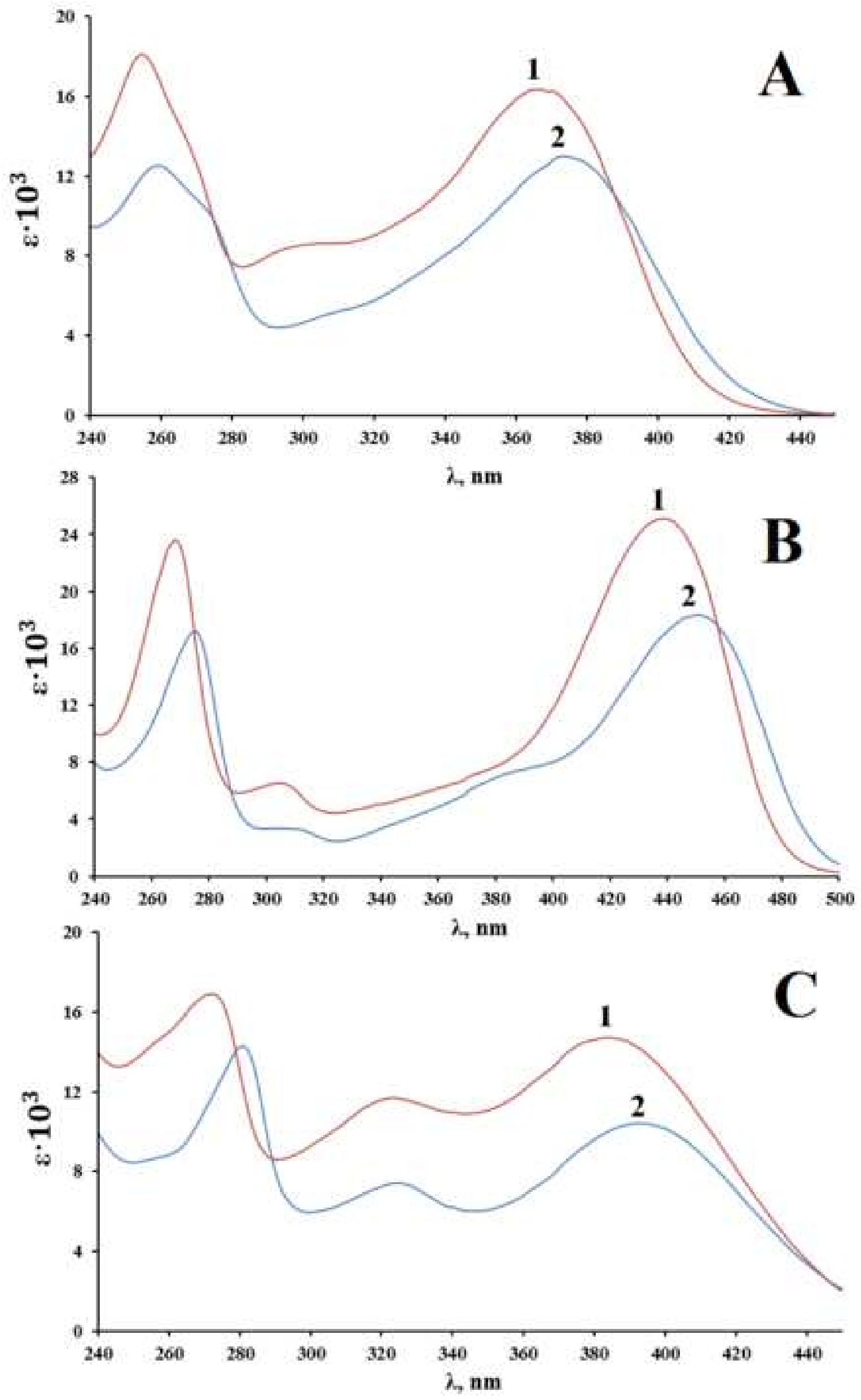

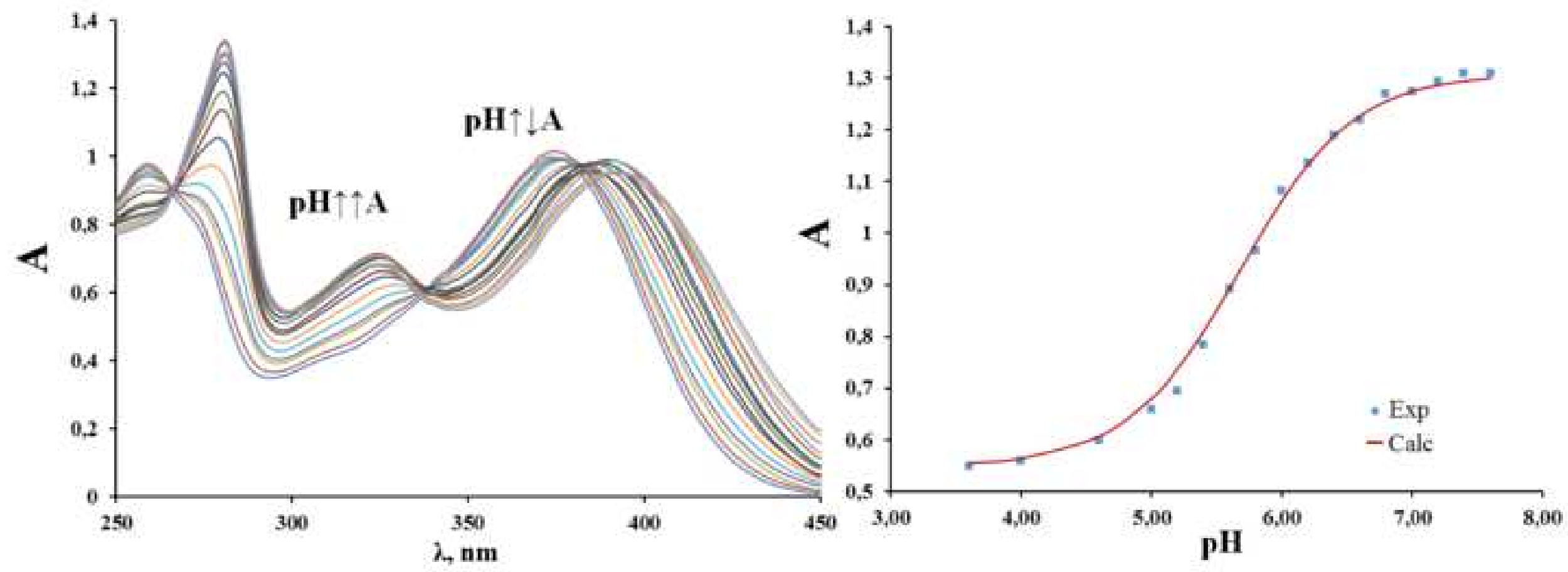

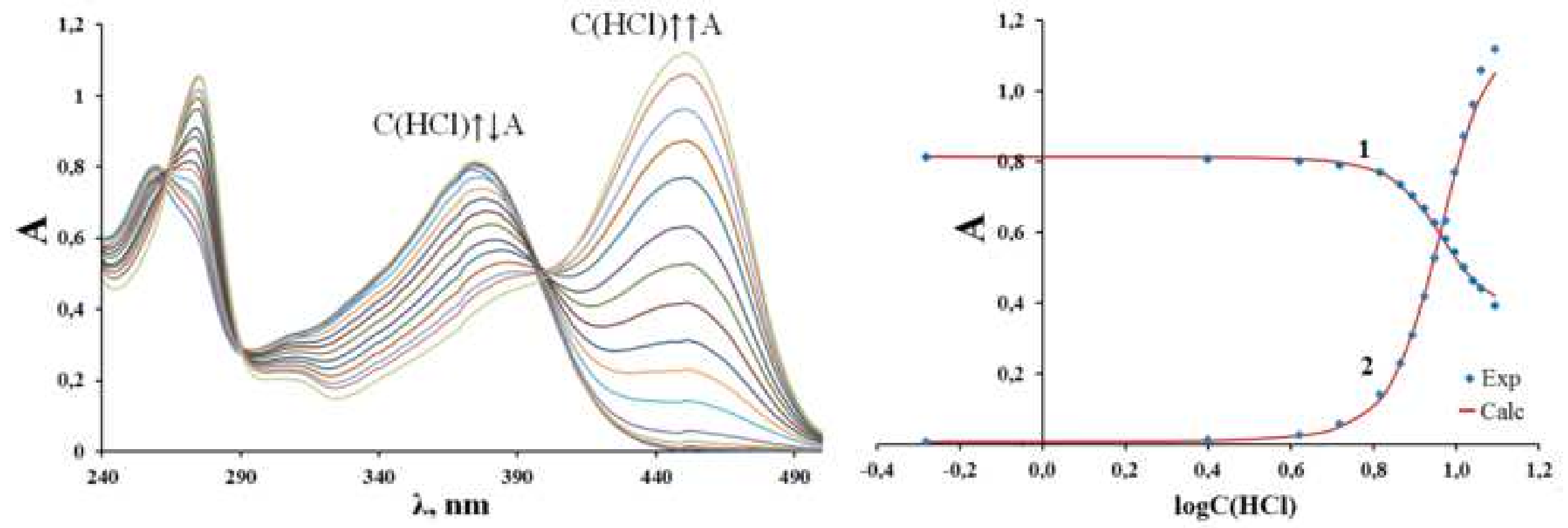

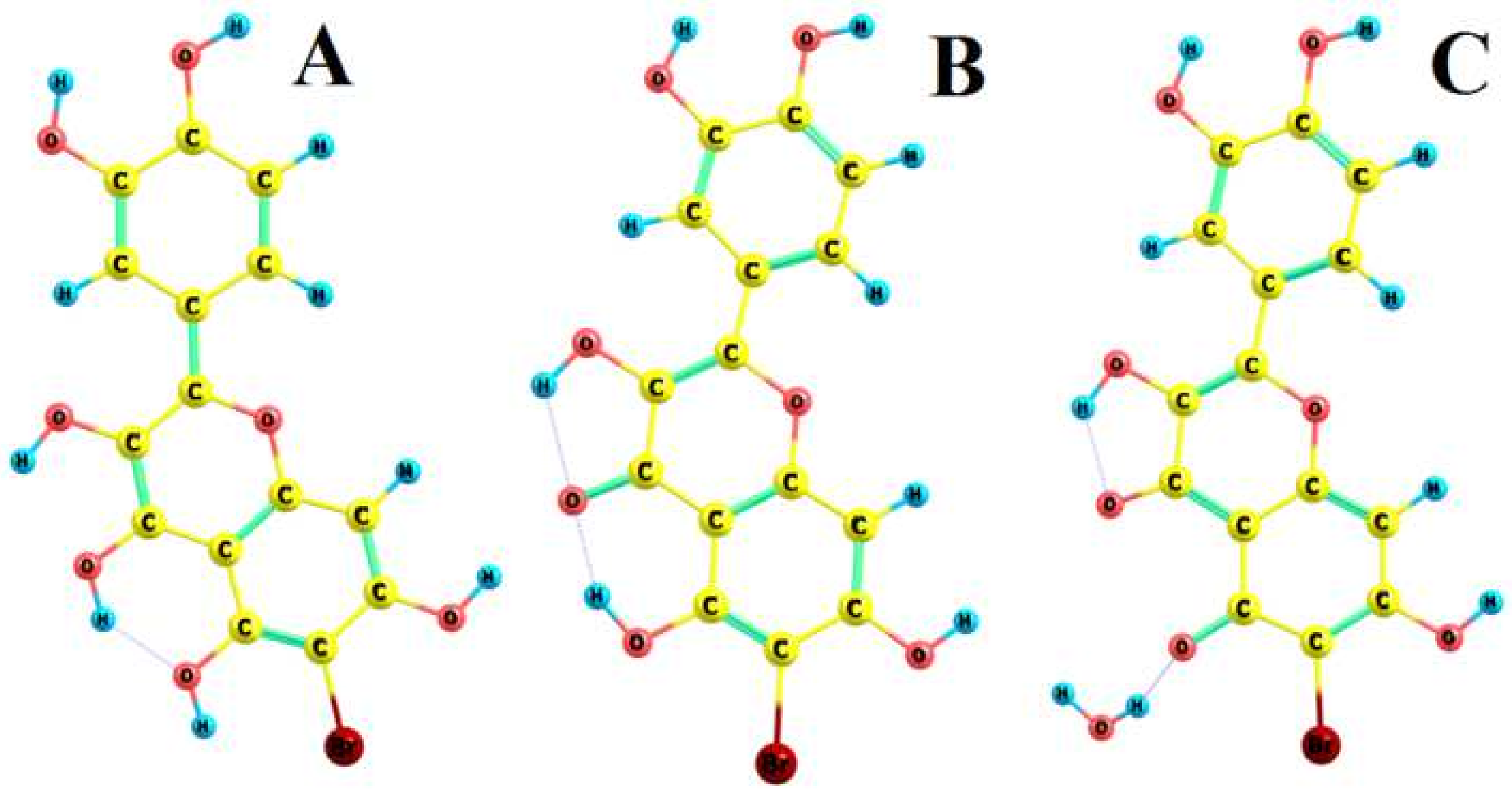

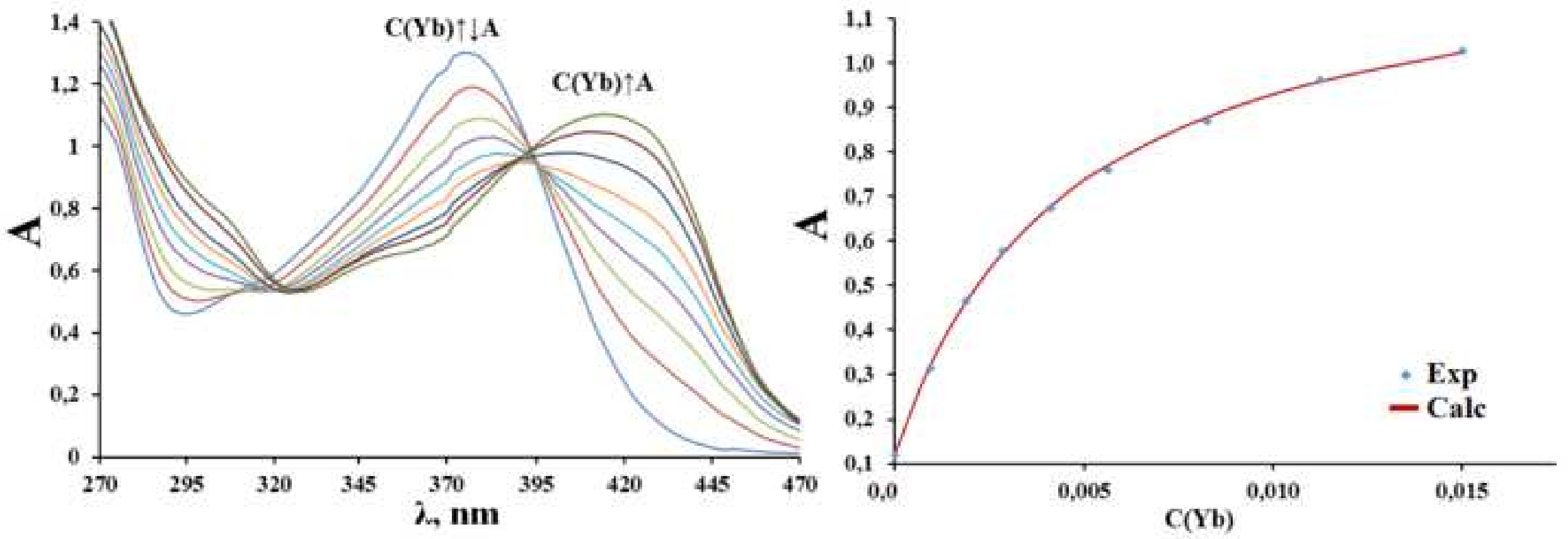

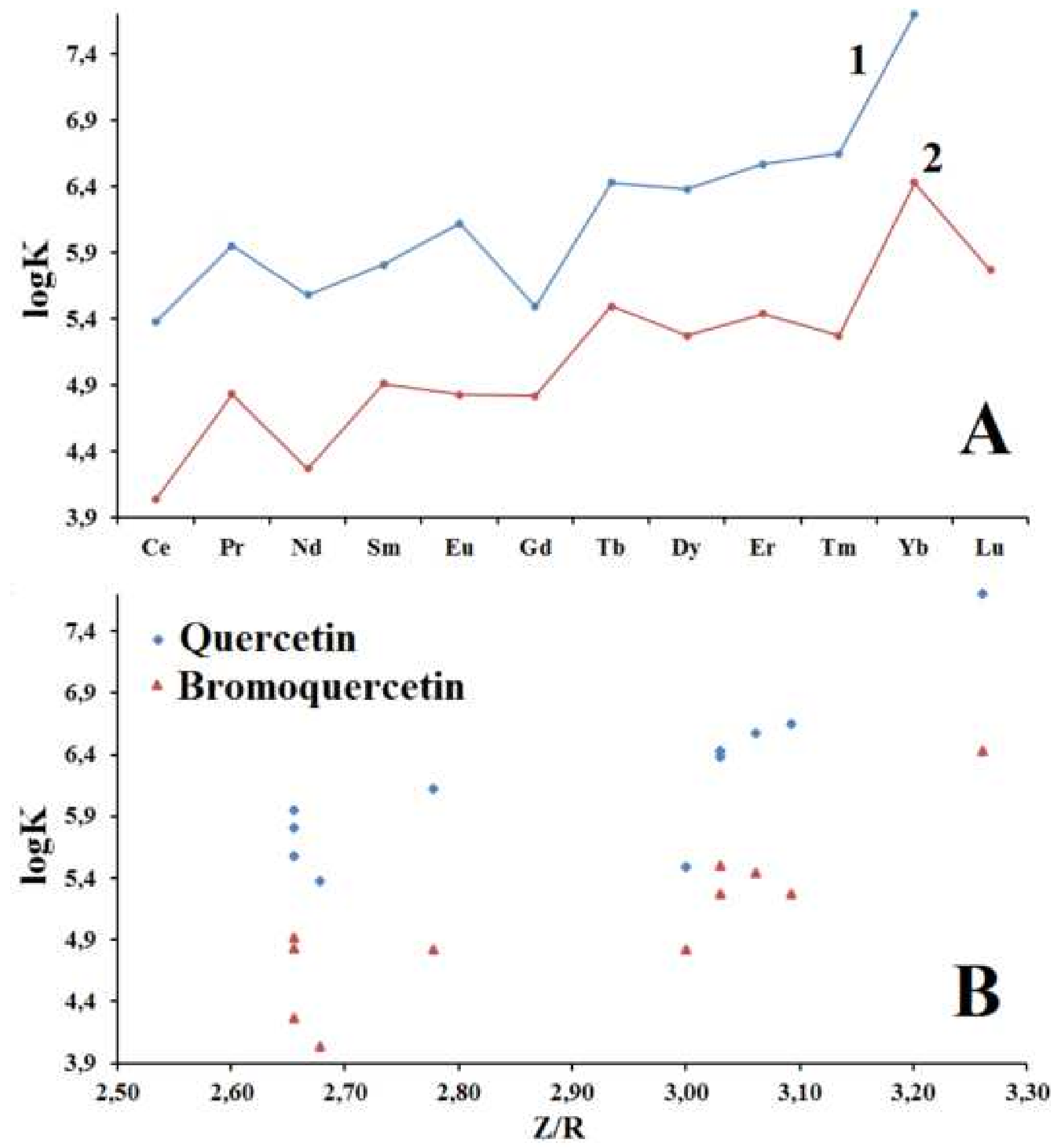

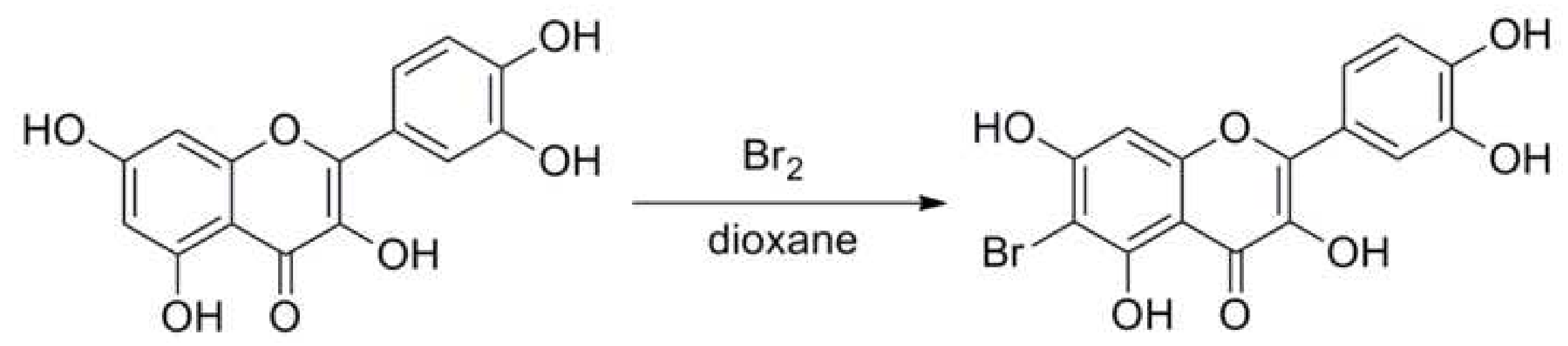


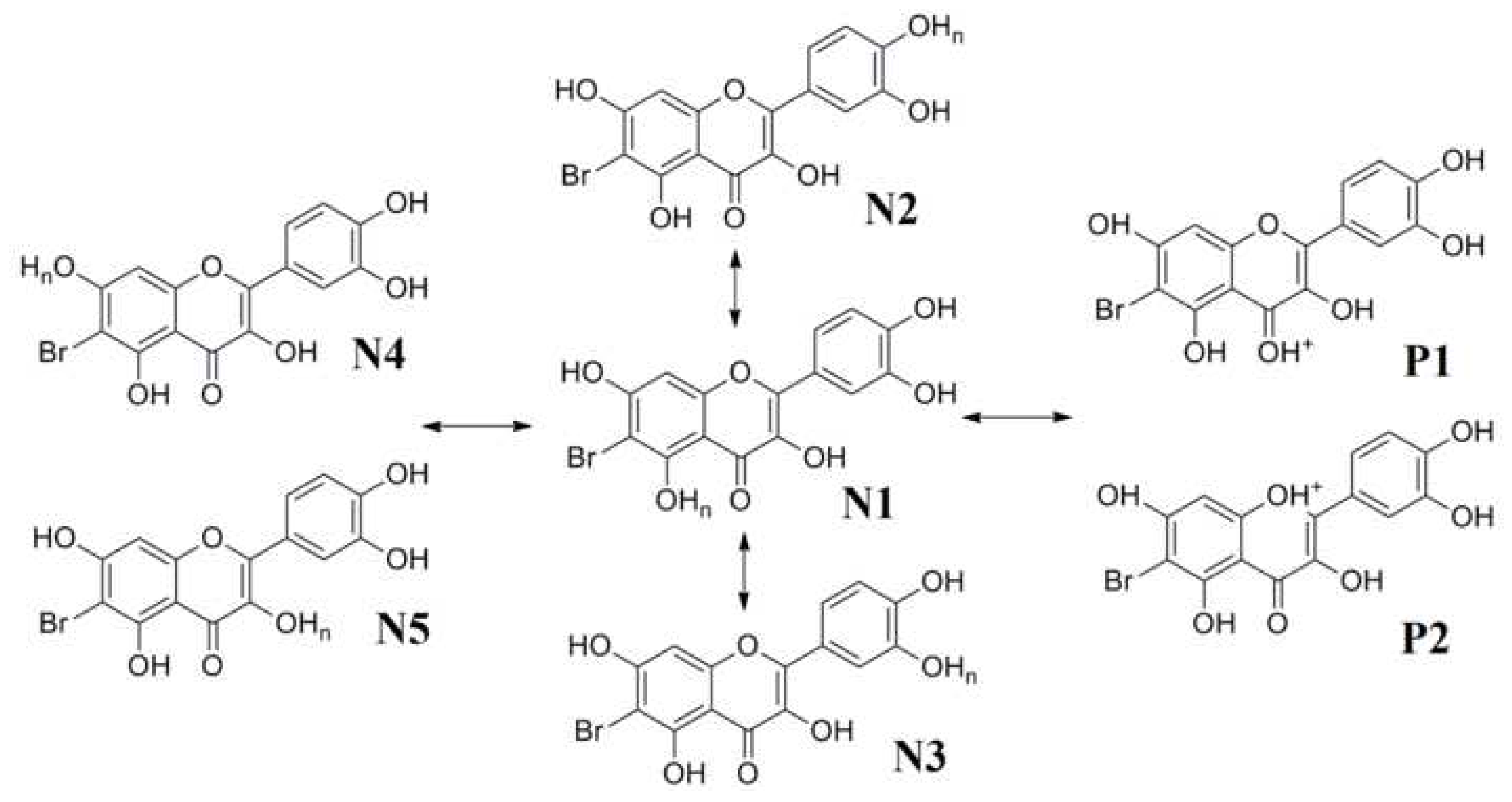




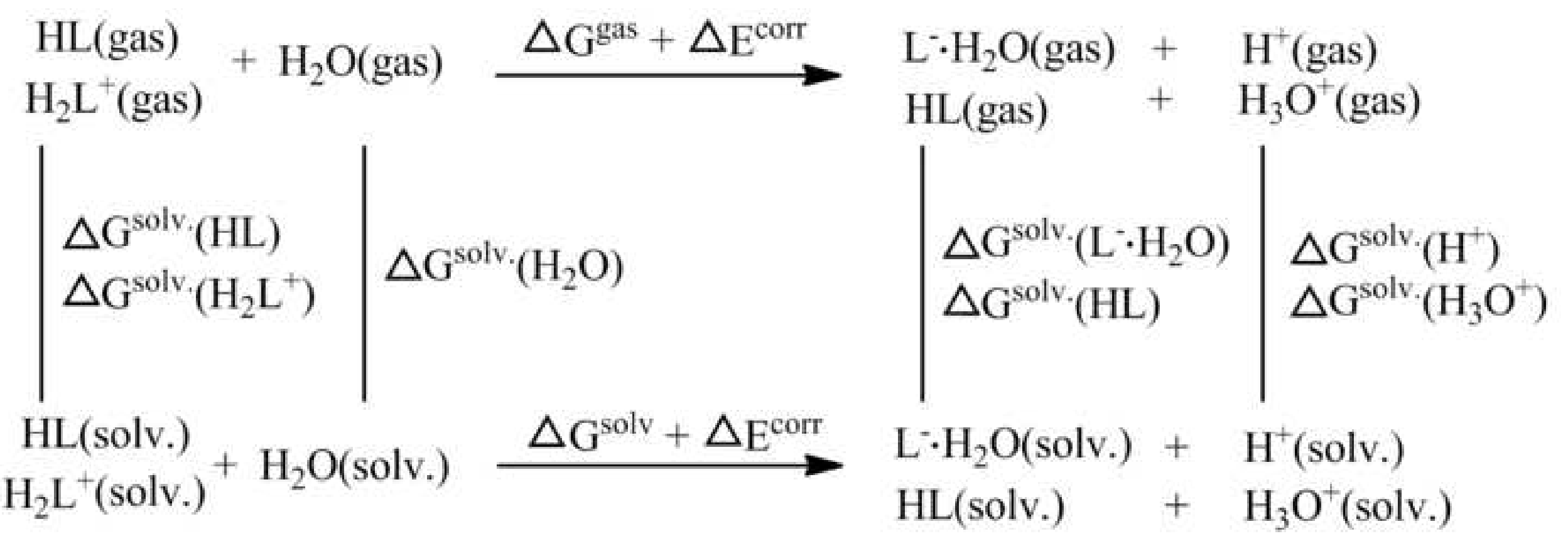


Click here to access/download Supplementary Material Supplementary.docx 